\title{
How and with What Frequency do Social Studies Teachers Ask Questions?
}

\author{
Güneş Kılınç*a, Hüseyin Çalışkan ${ }^{\mathrm{b}}$
}

\begin{tabular}{l} 
Article Info \\
\hline DOI: 10.14686/buefad.465630 \\
\hline Article History: \\
Received 29.09.2018 \\
Accepted $\quad 14.03 .2019$ \\
Published $\quad 30.06 .2019$ \\
\hline Keywords: \\
Social Studies \\
Teacher \\
Question type \\
\hline Article Type: Research Article
\end{tabular}

\begin{abstract}
The objective of this study was to examine the level and number of questions that social studies teachers ask during the lessons they teach. Case study which is one of the qualitative research methods was used on the study group consisting of a total of five social studies teachers at the city of Sakarya during the 2013-2014 school year four of whom are working at a state secondary school and one of whom is working at a private secondary school three of whom are male and one of whom is female."Observation Form", "Interview Form" and "video records" were used as data acquisition tools. The data obtained in the study were analyzed via descriptive analysis method. According to the results of the study, it was concluded that social studies teachers ask very low level simple recall and memory question in addition to convergent questions meaning questions that have only one acceptable answer. Teachers have also directed evaluation questions to students, however it was determined that divergent questions and questions related with operations were never asked. Teachers generally asked the highest number of questions during teaching-learning processes, a small number of questions have been asked during the introduction stage of the courses whereas questioning behavior was not observed during the conclusion stages.
\end{abstract}

\section{Sosyal Bilgiler Öğretmenleri Nasıl ve Ne Kadar Soru Soruyor?}

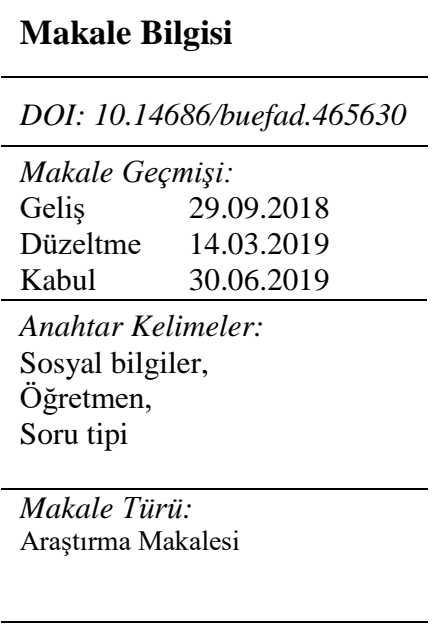

\begin{abstract}
$\ddot{O} \mathbf{z}$
$\mathrm{Bu}$ araştırmada, sosyal bilgiler öğretmenlerinin sınıf içi ders işleme süreçlerinde sormuş oldukları soruların düzeyini ve miktarını incelemek ve örneklerle betimleyerek yorumlamak amaçlanmıştır. Nitel araştırma yöntemlerinden durum çalışmasının kullanıldığı araştırmanın çalışma grubunu 2013-2014 eğitim ve öğretim yılında Sakarya ilinde dördü devlet ortaokulunda bir tanesi özel ortaokulda görev yapan iki erkek iki kadın olmak üzere dört sosyal bilgiler öğretmeni oluşturmuştur. Veri toplama aracı olarak ise araştırmacılar tarafından geliştirilen "Gözlem Formu, "Görüşme Formu" ve "Video Kayıtları" kullanılmıştır. Araştırmada elde edilen veriler betimsel analiz yöntemiyle analiz edilmiştir. Araştırmanın sonuçlarına göre sosyal bilgiler öğretmenlerinin en çok alt düzeyde nitelendirilebilecek basit hatırlama ve bellek soruları ile yakınsak sorular yani kabul edilebilir tek cevabı olan türde sorular sorduğu sonucuna ulaşılmıştır. Öğretmenler öğrencilere değerlendirme soruları da yöneltmiştir ancak ıraksak soruların az, işleyişle ilgili soruların ise hiç sorulmadığı tespit edilmiştir. Öğretmenler genellikle en fazla soruyu öğrenme öğretme süreçleri esnasında sormuş, derslerin giriş bölümünde az soru sorulmuştur.
\end{abstract}

\footnotetext{
*Corresponding Author: gunesbayrak@gmail.com

${ }^{a}$ Sakarya University, Sakarya, Turkey, ORCID: https://orcid.org/0000-0002-3007-1120

b Doç.Dr., Sakarya University, Sakarya, Turkey, ORCID: https://orcid.org/0000-0001-6849-1318
} 


\section{Introduction}

The term "question" is defined in the dictionary of the Turkish Linguistic Society as "Verbal or written statement directed to someone else in order to learn something which requires a response". According to another definition, the term question represents incomplete statements formed to stimulate the curiosity of individuals thus enabling them to learn (Akbulut, 1999). Questions have an important place in our lives ranging from ordinary questions that we use during our daily lives to questions that require a certain expertise (Aydemir and Çiftçi, 2008). Questioning, which is accepted as a method for stimulating thinking, is required for people to work their minds. Learning becomes more meaningful with questions and one starts thinking as soon as questions are directed to him/her on a specific topic (Özden, 2003). Learning is more effective when the learner is open to thinking and when he/she tries to find answers to certain questions. It is a fact that permanent and meaningful learning can take place only in such a manner. We see that asking questions is a very important to ensure that the relevant mental processes of students are activated and that they carry out the required questioning for the issue at hand. Asking questions is an activity that stimulates thinking and enables learning. It can be identified as the most important weapon in the teachers' arsenal of teaching processes. Asking questions is one of the fundamental tools that is used to determine at what level students have gained the targeted learning outcomes (Çalışkan, 2011).

Asking questions is used as a method in all stages of education and in all courses both in order to enable real thinking as well as to determine at what level the students gain the targeted learning outcomes. As is the case for all other courses, a social studies lesson cannot be thought which does not include the question-answer method. Question-answer method will constitute a significant portion of the teaching-learning process regardless of the gains and activities. It can be stated that this method has to be used intensively and in a conscious manner in order to ensure that students actively take part in the learning-teaching processes. Asking questions has an important place for active learning with regard to directing students to superior learning because it activates the mind of the student and encourages him/her to think actively (Açıkgöz, 2014).Teachers have to develop strategies that direct one's self to good questioning, problem solving and complex thinking in order to ensure that effective learning takes place in the classroom environment. A social studies teacher first has to specialize in questioning in order to reach this goal and to acquire information about the different types of questions (Demirkaya, 2011). Increasing consciousness of teachers with regard to question types and the effects of questions on student response can contribute to attaining a more effective learning. Different question types required different answers (Şevik, 2005). Different questions should be asked according to the topics, areas of learning and outcomes. The teacher will be able to shape his/her questions accordingly when he/she has knowledge of different question types and the contributions of these question types on learning. The teacher will direct questions at a level of recall based on the topic and the outcome or he/she will direct higher level questions which encourage thinking.

Questions have been subject to various classifications by different researchers based on certain criteria. While answers are taken as basis in some classifications, others have focused on the goals or the questioning method and sometimes the starting point has been the answer to how the question is asked. Açıköz (2014) has classified question types into two as single and multiple choice questions. Whereas Sönmez (2001) has classified the question types as open ended and close-ended questions according to the level of the goal and as questions according to methods in addition to questions according to asking styles. Kerry (1999) analyzed questions in detail in his study entitled "Effective Questioning" in which nine different question types were put forth: recall questions, naming questions, observation questions, control questions, pseudo questions, analysis questions, synthesis questions, evaluation questions, problem solving questions (Cit. Büyükalan Filiz, 2004). In addition to all these classifications, the method that is most widely used for classifying questions according to their levels is the hierarchical classification of Bloom et.al.(1956) for the targets in the cognitive area including the stages of knowledge, comprehension, application, analysis, synthesis and evaluation. In this classification, educational goals and questions are listed in increasing levels of complexity. Accordingly, the simplest goals/questions are at the knowledge stage, whereas the most complex goals/questions are at the evaluation stage (Açıgöz, 2003). Another classification is that of Selçuk (2000) made with regard to which category the questions of the teachers can be examined. In this classification; there are five question categories which are simple recall and memory questions, convergent questions (questions with a single acceptable answer), divergent questions (questions with various possible answers), evaluation questions (questions that put forth judgments) and procedural questions (questions related with organization, discipline and the structure of the course). Simple recall and memory questions along with convergent questions (questions with a single acceptable answer) can be evaluated as low level questions since they require certain answers. The students do not need to think hard when answering such questions. Whereas divergent and evaluation questions are expressed as questions that push the mental limits of 
students thus forcing them to think at high levels since they might require different types of answers. The thinking levels of students are affected from the questions directed by the teachers. If the students are faced with low level questions, they tend to prefer a low level thinking process. If the students are asked questions at high cognitive levels, they will tend to be more creative and lean towards versatile thinking. Studies have put forth that most of the questions asked by teachers are low level questions with simple answers that are solely dependent on textbooks (Selçuk, 2001).Classification of the questions contribute to understanding the nature of the class, because different types of questions require different answers. For example, it might be a problem if the number of low level questions is too high and if high level questions are almost never asked when we examine the questions asked in the classroom.Because the thinking and speaking skills of the students will have been restricted. The teacher who realizes this can make a more balanced plan by using both question types for the next lesson. Thus, both question types are required for different times and different goals. Effective learning takes place when question types are used together not separately (Şevik, 2005). In conclusion, it can be stated that teachers who are more aware of the question types will use this method much more effectively.

The number of questions asked during a lesson and the time period of the lesson during which these questions are asked are important issues. Teachers ask questions during the introduction, learning-teaching and evaluation periods of the courses. According to Şevik (2005), teachers ask many questions during a regular day. According to study results, it is possible to state that the question-answer method coversabout four fifths of the time period spent at school (Gall, 1970; Stevens, 1912). Whereas Kerry (1998) states that teachers ask 43,6 question per lesson and that they can reach up to about 1,5- 2 million questions throughout their careers. The number of questions asked during lessons can be evaluated as well as the number of questions asked per different periods. The questions asked by teachers during inclass teaching process provide rich data for the theoretical and application fields. It is thought that this study will also contribute to the relevant field by defining the current situation as a result of the evaluation of the questions asked by teachers in the classroom with regard to their level and quantity. It can also be stated that the data obtained from this study will be beneficial to primarily social studies teachers as well as researchers and those who apply the results during the teaching process with aims of increasing success and efficiency.

The objective of this study was to examine the amounts and levels of questions asked by the social studies teachers in-class during the lesson and to describe and evaluate them by way of examples. Answers to the following questions were sought:

- What is the level of the questions asked by the social studies teachers in-class during the lesson?

- What is the amount of the questions asked by the social studies teachers in-class during the lesson?

\section{Method}

\section{Research Model}

Case study pattern which is one of the qualitative research patterns was used in the study. Case study is a type of research that is based on the questions of how and why which enable the thorough examination of a case or event that the researcher cannot control (Yıldırım and Şimşek, 2011). Whereas case study according to Glesne (2013) means an intensive focus on the subject in question. The objective of a case study is to examine a certain state and to put forth detailed conclusions (Köse, 2010). In this study, the questioning processes of teachers were examined in detail and this was tried to be reflected in the study results. Face-to-face interviews were carried with the teachers during the study period, observation times were tried to be kept long and the researchers tried to spend the maximum amount of time with the teachers on the days of the observations. In this way, detailed information about the teachers could be obtained and the research topic was studied in detail.

\section{Study Group}

The research group consisted of Social Studies teachers working at the Erenler and Serdivan districts of the city of Sakarya during the 2013-2014 academic year. Easily accessible case samplings were preferred when determining the teachers who were included in the study. In easily accessible case sampling, the researcher selects a case that is easily accessible which speeds up the study. Hence, it is widely used in qualitiative studies (Yildirım and Şimşek, 2011). Five social studies teachers participated in the study on a voluntary basis as part of the pilot application. The properties of the teachers who participated in the study are shown in Table 1. 


\begin{tabular}{|c|c|c|c|c|c|}
\hline Participants & Gender & Age & $\begin{array}{l}\text { Professional } \\
\text { Seniority } \\
\text { (Years) }\end{array}$ & Institution & $\begin{array}{l}\text { Graduation } \\
\text { (Bachelor's } \\
\text { Degree) }\end{array}$ \\
\hline $\mathrm{T} 1$ & Female & 43 & 20 & $\begin{array}{l}\text { State } \\
\text { School }\end{array}$ & $\begin{array}{l}\text { Faculty of } \\
\text { Science and } \\
\text { Literature }\end{array}$ \\
\hline $\mathrm{T} 2$ & Male & 40 & 12 & $\begin{array}{l}\text { State } \\
\text { School }\end{array}$ & $\begin{array}{l}\text { Faculty of } \\
\text { Education }\end{array}$ \\
\hline T3 & Female & 29 & 7 & $\begin{array}{l}\text { Private } \\
\text { School }\end{array}$ & $\begin{array}{l}\text { Faculty of } \\
\text { Education }\end{array}$ \\
\hline $\mathrm{T} 4$ & Male & 41 & 13 & $\begin{array}{l}\text { State } \\
\text { School }\end{array}$ & $\begin{array}{l}\text { Faculty of } \\
\text { Science and } \\
\text { Literature }\end{array}$ \\
\hline
\end{tabular}

The teachers who participated in the study were coded as T1, T2, T3 and T4. T1 who participated in the study is a 43 year old female. She is a graduate from the Faculty of Science and Literature and she has been working as a teacher for 20 years. T2 is a 40 year old male. He has graduated from the Faculty of Education Department of Social Science Teaching and has been working as a teacher for 12 years. T3 is a 29 year old female. She has graduated from the Faculty of Education Department of Social Science Teaching and has been working as a teacher for 7 years. T4 is a 41 year old male. He is a graduate of the Faculty of Science and Literature Department of History and he has been working as a teacher for 13 years.

\section{Data Acquisition Tools}

The "observation form" and the "interview form" developed by the researchers along with the "video records" were used as data acquisition tools in the study.

Observation Form: The level of the questions asked by the teachers during the class was examined using the observation form which was prepared based on relevant studies. The study carried out by Selçuk (2001) was examined closely when preparing the observation form and a form for determining the level and quantity of the questions asked was prepared. The observation form which was prepared in draft form was examined by four academicians who are specialized in this field. These specialists examined the form in terms of content, comprehensibility, appearance and the observation form took on its final form following the completion of the required corrections put forth by the specialists. According to expert opinions, the eight item observation form developed by the researchers consist of two sections. The first section includes five categories including the classification made by Selçuk (2001) to determine the level of questions; simple recall and memory questions, convergent questions (questions with a single acceptable answere), divergent questions (questions with several probable answers), evaluation questions (questions that put forth a judgment) and procedural questions (questions related with organization, discipline and the structure of the lesson). In this section, a triple evaluation was used as "never", "sometimes", "most of the time" and the items in this form for which no behavior was observed were evaluated as "never", whereas those which were observed were evaluated as "sometimes" or "most of the time". Whereas the second section is the one that includes three items which have been designed to determine the number of questions that the teachers ask in the classroom during the "preparation, learning-teaching and end of course" stages. In this section, evaluations were carried out as "never", "1-4 questions" and "more". In addition, there was also an "explanation" section next to each item on the observation form in order to enable the recording of anecdotes. There was also a directive at the beginning of the form which declared that this observation form was designed so as to determine the number of questions asked by the teachers as well as the levels of the questions.

Interview Form: Draft questions have been written by the researchers within the scsope of the study in order to learn the opinions and thoughts of teachers related with questioning process and these questions have been examined by four experts in the field. The experts evaluated the draft questions with regard to scope, appearance and comprehensibility. The form was finalized following the changes made in accordance with expert opinions and suggestions. There is a question in the interview form prepared to determine the opinions and thoughts of teachers related with the questioning process which is about the period of the class when they ask questions and this question has been examined within the scope of the study. Interviews about the questioning process were 
conducted with the teachers following the observations and these interviews were recorded via audio recorders which were then decoded by the researchers.

Video Records: The lessons during which observations were carried out were recorded using video recorders in order to ease the data acquisition and analysis processes of the study. The required approvals were taken from the contributing teachers as well as the instutitions prior to the recordings. One of the researchers attended all lectures together with the teachers and recorded the lesson paying attention not to disrupt the natural order of the classroom. The 32 hour long video records including all the observed lectures were decoded by the researchers.

\section{Validity and Reliability}

Various strategies have been used in this study in order to provide the required validity and reliability. Methods such as long term interaction, in-depth data acquisition, variation, expert analysis and participant confirmation are suggested in order to provide the required internal validity (Yıldırım and Şimşek, 2011). The duration of the study was tried to be kept long in order to ensure internal validity in addition to using observation and interview methods together as data acquisition methods. In addition, researcher variation was implemented in scope of which two researchers carried out the analysis separately after which their results were compared. Observation and interview forms which were used as data acquisition tools were presented to field experts for analysis and expert opinions were taken. Another method that was implemented to ensure internal validity was participant confirmation. In this method, feedback regarding the results is asked from the people from whom the analyzed data were acquired or with whom the interviews were conducted (Merriam, 2013). In this study, the transcripted texts were provided to the participants thus requesting participant confirmation.

Detailed description and purposeful sampling are suggested in order to increase the transferability of the study results (Yıldırım and Şimşek, 2011). Accordingly, the data acquired during the study were presented in detail and were tried to be supported with direct references.

\section{Procedure}

First of all, a social studies teacher was observed for a period of six lessons which were recorded using a video camera as part of a pilot study. These recordings were used during the period of developing the data acquisition tools required for the study and this pilot application was taken into consideration when planning the study. In addition, the consents of teachers and school administrators who will participate in the study were taken prior to the data acquisition process. Volunteer teachers were selected for the study who were informed about the research and the recording time was tried to be kept at a maximum level in order to eliminate the observer effect. Afterwards, each of the social studies teachers who made up the study group during the four week period of the first semester of the 2013-2014 academic year were observed for a period of eight lessons during which the observation forms were filled and the lessons were recorded using a video camera. Following the observation and video recordings, interviews were carried out within the scope of the "Interview Form" prepared to determine the opinions and thoughtws of the participant teachers with regard to the questioning process which were also recorded using an audio as well as a video recorder. Finally, the data acquired from the interviews and video recordings were analyzed.

\section{Data Analysis}

The data acquired from the study were subject to descriptive analysis. The data acquired are summarized and interpreted in accordance with pre-determined themes during descriptive analysis. Direct quotations are frequently used in descriptive analysis in order to be able to reflect the opinions of the interviewed or observed individuals in a striking manner. The objective in such an analysis is to be able to present the results in an orderly and interpreted manner (Yıldırım and Şimşek, 2011). Accordingly, all video and audio recordings obtained as a result of the observations and interviews were decoded and transcripted.

The behaviors during each course by the four teachers who comprise the participant group of the study were observed by all researchers separately after which they were recorded in the observation form which was prepared within the scope of the study. Video recordings were used in order to increase the reliability of the data acquired from this form thus enabling a second researcher to repeat the same procedure. Average of the behavior frequencies in the observation forms were calculated at the end of the observation process. The analyses were tried to be sampled by adding direct citations to the results obtained from observations. The data acquired from the interviews were used to support the study findings. 


\section{Findings}

T1 was observed for eight course hours while teaching the "Life on Earth" unit to $6^{\text {th }}$ graders and the "Step by Step Turkey" unit to $5^{\text {th }}$ graders; T2 was observed for eight course hours while teaching the "Population in our Country" unit to the seventh graders; T3 was observed for eight course hours while teaching the "Life on Earth" unit to the seventh graders and the "Population in Our Country" unit to the seventh graders; T4 was observed for eight course hours while teaching the "Life on Earth" unit to the sixth graders and the "Journey in the History of the Turks" unit to the seventh graders. A single observation form was kept in order to provide subject consistency in cases when the lessons were two hours in a row. A total of six observation forms were kept for T1, four for T2, four for $\mathrm{T} 3$ and six for T4. Interviews were carried out within the scope of the study after all these observeations were completed with the teachers. The following results were obtained as a result of the analysis of the data acquired from the teachers via observation, interviews and video recordings:

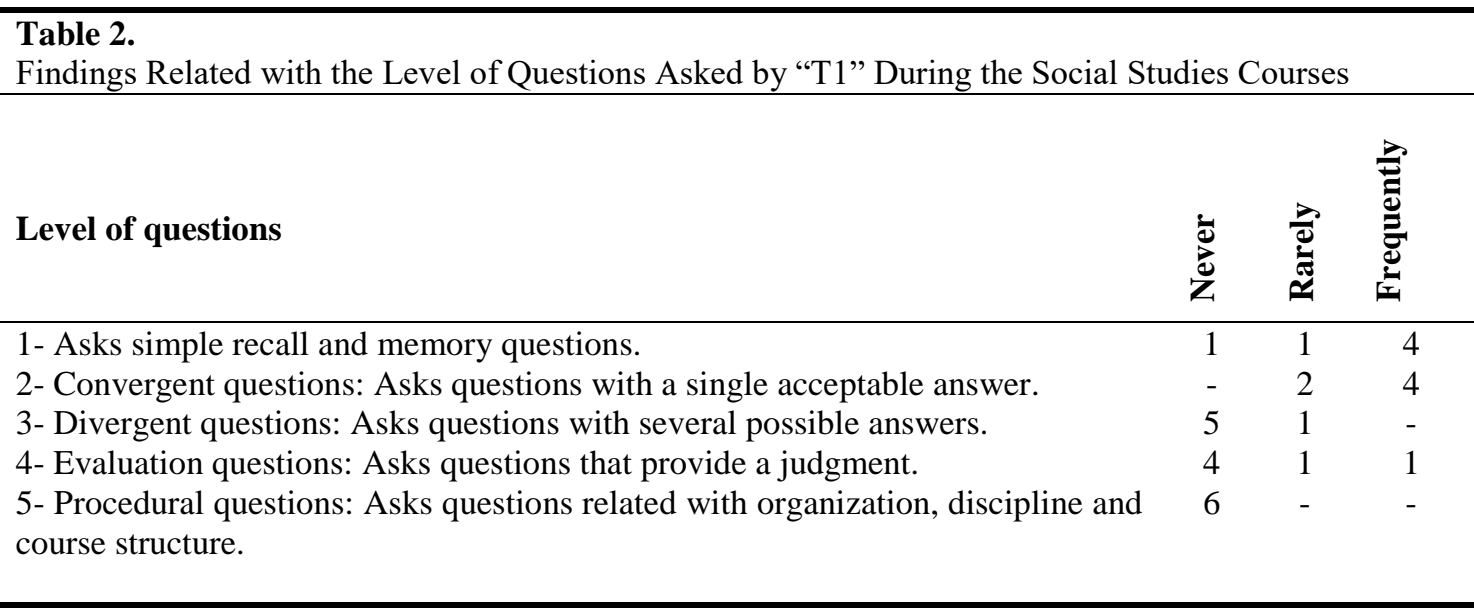

T1 mostly asked simple recall and memory questions to the students during the lessons along with convergent questions which have a single acceptable answer. Questions at evaluative levels were also asked, however it was observed that the teacher did not ask divergent questions which have several possible answers as well as procedural questions. T1 stated the following during the interview regarding the level of questions asked:

"I really enjoy questions that can force the brains of the children, leading them to make syntheses and interpretations. I pull the question further back so that they can think and make connections thus reaching the point where I want them to reach. So, I sometimes think of it as a mathematical balance, that is I do not see social studies in a strict manner, I don't consider it as straight and structural information; I give importance to synthesis and interpretation in social studies."

The statements of $\mathrm{T} 1$ regarding the level of the questions contradict with observations. It was observed that T1 mostly asks simple recall and memory questions to the students along with convergent questions and it was also observed that $\mathrm{T} 1$ does not ask sufficient number of questions that require higher levels of thinking.

The following question-answer dialogue examples were provided as proof of these findings:

T1: Yes now I ask you this. What is fact? I want a sentence on fact. (Repeats and writes the concept on the board) Student: Fact is something accepted by everyone that is based on scientific studies... how shall I put it... based on scientific studies...

T1: It is sentences or knowledge accepted to be correct by everyone which have been proven as a result of scientific studies.

It is seen that the question in this dialogue is a simple recall and memory question. Because here the teacher asks for a definition and demands an example related with the question.

T1: Yes (says the student's name) tell me now?

Ögrenci: What?

T1: What? What is your responsibility as a student? 
Ö̆̆renci: My responsibility as a student is to obey the rules of the school

T1: What else?

Ögrenci: Participate in school activities

The question in this dialogue can be evaluated as a convergent (questions with a single acceptable answer) question. Here, the teacher asks the responsibilities of a student. This question has various specific answers and hence it can be accepted as a convergent question.

\begin{tabular}{l} 
Table 3. \\
Findings Related with the Number of Questions Asked by "T1" During Social Studies Courses \\
\hline \\
Number of questions during the lesson
\end{tabular}

It was determined during in-class observations that the teacher asked fewer questions during the preparation stage in comparison with the learning-teaching stage. Whereas the conclusion stage was not observed since in general the end of course bell rang while the teacher was still in the learning-teaching stage.

Following the observations carried out related with the questioning processes, T1 stated the following related with the frequency of questions asked during the lessons:

"This duration is not always the same. It may vary depending on the topic. Depending on the content of the topic. It can also change depending on the level of the classes for me. So if the class is a good high level one, I can directly start with a question. I know that they have a certain knowledge but if the level is low I prefer first to go over the topic and the ask questions. It is during the middle or towards the end of the lesson for us old teachers who have been teaching for over 15-20 years. But one can ask questions whenever he/she feels like it in the new teaching system. My style is this: I am not a fan of asking questions prior to giving them the required knowledge. Because students do not always come to the lesson prepared. If I ask a question directly, they can respond in connection with their daily lives, but they cannot respond technically or terminologically.'

$\mathrm{T} 1$ put forth during the interview that he generally asks most of the questions during the middle or towards the end of the course. When the observation results were examined, it was observed that T1 generally starts off the lesson with a question but that he asks the highest number of questions during the learning-teaching periods. This supports the statements made by T1 during the interview. However, the statement by the teacher that he asks questions at the end of the lesson contradicts with the observation findings.

\begin{tabular}{l} 
Table 4. \\
Findings Related with the Level of Questions Asked by “T2” During the Social Studies Courses \\
\hline \\
Level of Questions
\end{tabular}


The teacher frequently asked divergent questions, that is questions with various possible answers, to the students during the observed lessons in addition to a sufficient number of recall and memory questions, convergent questions and evaluation questions. No procedural questions were asked.

The following question-answer dialogue examples were provided as proof of these findings which reflect the question levels:

T2: So, what kind of problems do people living in slums experience as a result of their migration?

Student: Teacher, nature is damaged, amount of green areas decreases

T2: This is one of the results of migration, yes. The amount of green areas decreases since the slums are built in a random manner. Yes?

Student: Benefits such as electricity, water decrease Teacher

In this dialogue, the teacher asks about the possible results of migration. This question has certain specific answers and hence it can be accepted as a convergent question.

T2: So, let us now mention this, do we consider these people in accordance with the United Nations Criteria that if they are above the age of 65 and a consumer group, do we consider them as people who are of no use anymore, who just sit around and consume? Or should we consider them as such? (pause) Yes?

Student: We shouldn't consider them in that way teacher, they have also worked during the ages of 18-64. That is why we shouldn't.

T2: Ok, so once they also produced something. Children were consumers and they were working. What else? So let's consider a 64-65 years old engineer, an architect, a politician, a lawyer, a doctor or an athlete. Can't people make use of them? Can't we make use of these people in a certain manner?

Student: We can.

T2: So, how will we go about it?

Student: Their experiences teacher

T2: We will make use of their experiences in life, right? Look, working is not only running around or working at a factory or a construction site. Those people also have certain experiences, they must have faced many different things during their lives. They must have experienced things that are similar to what we experience now. So we should make use of their experiences, all right? In this sense, elderly people make up the mental structure of the society.

In this dialogue, the teacher asks the students how we should benefit from people above the age of 65 . There may be many different perspectives related with this issue and hence it requires interpretation, therefore this can be evaluated as a divergent (having various possible answers) question.

T2: Who went to Istanbul? (asks a student) When you went to Istanbul, what were your thoughts and opinions about the city for instance? What do you think about that city?

Student: Teacher, it's so crowded that it's difficult to even walk.

T2: Difficult to even walk.

A.Ö.: Teacher, the population is so high and the city is not that large

T2: So you thought of the city as one with a high population

A.̈̈.: Yes, teacher and industry is very developed. The hospitals and all are very developed.

In this dialogue, the teacher asks the student his opinions and thoughts on Istanbul. This can be evaluated as a judgment question because the teacher is asking for an evaluation.

Table 5.

Findings Related with the Number of Questions Asked by "T2" During the Social Studies Courses 


\begin{tabular}{llcc} 
Number of questions during the lesson & & & \\
& & & \\
& & - & 4 \\
\hline 34- Preparation stage & 2 & 2 & - \\
35- Learning-teaching stage & & 2 \\
36- Final stage of the lesson
\end{tabular}

According to the observation results, T2 started the course by asking questions and asked the highest number of questions during the learning-teaching stages. A conclusion section was not observed in the following lessons abd either the bell rang during the learning-teaching stage or the recording was stopped. Following the observations carried out related with the questioning processes, T2 stated the following related with the frequency of questions asked during the lessons:

"Now first of all, I start by asking questions in the first minute of the lesson in order to rate the level of readiness of the students and to make the students focus on the lesson completely. After a while, that is after about ten minutes the level of focus of the student is at a maximm. Starting from the tenth minute the focus starts to diverge... I ask several questions between the tenth and twentieth minutes of the course. I try to ask students from different groups and also I try to make a distinction between male-female students. After the twentiet minute, I make a brief summary. Following that summary, I ask whether they understood the topic or not within the first half hour. And several minutes before the end of the course, I try to ask questions about issues I mentioned during the course." $\mathrm{T} 2$ stated that he starts the class by asking questions and continues to do so in the following stages as well as asking questions about the topic of the course several minutes before the class ends. When the observation results are examined, it can be observed that T2 generally starts the lesson by asking questions but that he asks the highest number of questions during the learning-teaching periods. This supports the statements of T2. Whereas the statement of the teacher regarding the questions asked at the end of the course contradict with the observation findings.

\begin{tabular}{l}
\hline Table 6. \\
Findings Related with the Level of Questions Asked by “T3” During the Social Studies Courses \\
\hline \\
Level of Questions
\end{tabular}

The teacher frequently asked simple recall and memory questions in addition to convergent questions which are those with only a single acceptable answer and in addition, the teacher has also asked questions at sufficient levels of convergence and evaluation. No procedural questions were asked.

The following question-answer dialogue examples were provided as proof of these findings which reflect the question levels:

T3: We learned about the different climates in the world. What were these? Who can list them? (Asks a student by name)

Student: Monsoon climate, polar climate, desert climate, temperate climate 
In this dialogue, the teacher asked the climates in the world. This was evaluated as a simple recall and memory question.

T3: So now, I'm going to ask this: What kind of economic activities can be made in the Eastern parts of the country?

Student: Animal rearing.

Here, the teacher asks opinions on the kinds of economic activities that can be carried out at a certain section of our country. The answers that can be given to this question are specific, therefore this can be accepted as a convergent question.

T3: Now, I want to ask this: "What is meant by: Istanbul is a city paved with gold,"?

Student: Job opportunities are more in Istanbul, we can earn more.

T3: Job opportunities are more, we can earn more. What else?

B.Ö: Teacher, we can take out part of the rock and soil of Istanbul.

T3: How do you mean?

A.̈̈: We can turn its stone into concrete. We can take its soil and turn it into agriculture (laughters are heard in the class)

T3: This is an interesting interpretation as well. Can you repeat it?

A.Ö: We can take the stone of the city and turn it into concrete. We can take the soil and turn it into agriculture. Throughout this dialogue, the teacher asked the students to make comments on a proverb. This was evaluated as a divergent question since different answers can be given.

T3: Yes, what would they be able to do without taking the university entrance exam? They would be able to continue their education at a state university. So, any opinions on this?

Teacher T3 asks the opinions of the students about the support of our country to people who had to migrate to Turkey from Syria; so this can be considered as an evaluation (judgment) question.

Table 7.

Findings Related with the Number of Questions Asked by "T3” During the Social Studies Courses

\begin{tabular}{|c|c|c|c|}
\hline Number of questions during the lesson & $\stackrel{\mathscr{\Xi}}{\stackrel{\Xi}{Z}}$ & 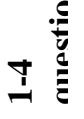 & $\stackrel{0}{\grave{c}}$ \\
\hline 34- Preparation stage & 1 & 2 & 1 \\
\hline 35- Learning-teaching stage & - & - & 4 \\
\hline 36- Final stage of the lesson & 4 & - & - \\
\hline
\end{tabular}

It was observed during the in-class observations that T3 asked questions during the beginning stage of the lesson but that the highest number of questions was asked during the learning-teaching stage. The conclusion section of the lesson was either not observed in general or the bell rang during the learning-teaching stage or the recording was stopped. Questioning behavior was not observed after the end of the topic.

$\mathrm{T} 3$ stated the following related with the frequency of questions asked during the lessons after the observations were over:

"I tend to ask more questions during the introduction part. Because I need to make connections with the previous topic. Pre-knowledge is questioned as well as past information. I continue the course after that. I ask more questions towards the end of the course in order to wrap up the issue. I take various notes to determine whether the students acquired the necessary knowledge during the course or not and if there are problems I note them down. Like start the next course from this and this issue. I have such notes."

Teacher T3 indicated that he asks more questions during the introduction and final stages of the course. Whereas according to the observation results, it was put forth that $\mathrm{T} 3$ tends to start the course by asking questions but that he asks the highest number of questions during the learning-teaching process. This is in accordance with the statements by T3 during the interview. Whereas the statement by the teacher regarding his opinion that he asks questions at the end of the course contradicts with the observation findings. 


\begin{tabular}{l} 
Table 8. \\
Findings Related with the Level of Questions Asked by “T4” During the Social Studies Courses \\
\hline \\
Level of Questions
\end{tabular}

During the observed lessons, the teacher frequently asked simple recall and memory questions along with convergent questions which have a single acceptable answer. In addition, the teacher also rarely asked several divergent questions which have various possible answers. T4 asked very few evaluation questions and no procedural questions.

The following question-answer dialogue examples were provided as proof of these findings which reflect the question levels:

T4: After the Kösedă War, the Mongols will invade Anatolia and the Anatolian Seljuqs will be demolished. Remember the first Turkish Chiefdoms, those that first sprang up in Anatolia? Which ones were they?

Student: Çaka Chiefdom

Student: The Artuqs

T4: Yes, there were five. Let us go over them again: Danishmends, Saltuqs, Artuqs, Mengüceks, Çaka Chiefdom and the Anatolian Seljuqs.

In this dialogue, the teacher asks the first Turkish chiefdoms that were established after the Közedağ War. Since this is a question based on remembrance, it can be considered as a simple recall and memory question.

T4: Let uls now ask this: caravanserais generally have high walls around them, why do you think? Why have they done such a thing? I want to see some fingers in the air, yes (says the name of a student)

Student: So that people cannot fire at them.

T4: You mean for protection. For protection, yes, bravo, so what else can it be for?

Another Student: To prevent robberies.

T4: That may very well be the case, so that people cannot rob their animals or belongings, yes, bravo, this is also the case. Look now, the most important reason is security.

In this dialogue, the teacher asks the students why caravanserais are surrounded by high walls. This was evaluated as a convergent question since most people would give similar answers.

T4: So, the whole country is divided among the students of the Emperor, that is the family of the Emperor. What does the Emperor do? What does he do with the family members and his children? He divides the country up among them? So, what is the danger in this? Who can tell?

Student: Teacher, they might quarrel after this divide and the siblings might separate and start quarreling with each other.

T4: Yes, they will quarrel with each other.

Another Student: Land will decrease teacher.

T4: How?

Student: The land of the country will decrease in size. 
T4: Ok, that's also the case, what else? For instance, let us think of a saying that we have, "many hands make light work" or in other words unity brings forth strength. So now, if unity brings forth strength, can we be strong if we separate and divide?

Student: No.

T4: So, we can be stronger when we are united, right Mehmet Ali? But what happens to our strength when we divide and separate...

Student: It decreases.

In this dialogue, the teacher asks about the problems related with an Emperor dividing the country up between his children. This was evaluated as a divergent (having more than one answer) question since it is open to interpretation and different answers can be given.

\begin{tabular}{l} 
Table 9. \\
Findings Related with the Number of Questions Asked by “T3” During the Social Studies \\
Courses \\
\hline \\
Number of questions during the lesson
\end{tabular}

According to the observation results, T4 asked questions at the beginning of the lesson, however T4 asked the highest number of questions during the learning-teaching periods. Conclusion period was not observed for the courses since in general either the bell rang during the learning-teaching period or the recording was stopped.

T4 stated the following related with the frequency of questions asked during the lessons after the observations were over:

"Yes, now we tried to spread out questions between the topics at hand and at the end of the topics, by projection. We are spreading out the questions prepared in Powerpoint. In between the subject topics. The questions in the books, preparation questions... For example, today we did the same thing for the preparation questions. We first talk about the preparation question in the book prior to the subject and during the course we ask questions based on how the lesson is going. And sometimes we ask evaluation questions at the end of the course to see how much the students have understood the subject."

T4 stated during the interview carried out that he asked the highest number of questions during and at the end of the subjects. Observation results indicate that T4 generally started the course by asking a question and that he asked the highest number of questions during the learning-teaching periods. This supports the statements by T4 during the interview. Whereas the statement by the teacher regarding the fact that he asks questions at the end of the course contradicts with the observation findings.

\section{Discussion and Conclusion}

It was concluded as a result of the observed lessons that social studies teachers ask simple recall and memory questions which can be evaluated as low level questions in addition to convergent questions which have a single acceptable answer. The teachers also asked questions indicating a certain judgment, however it was determined that they very rarely ask divergent questions which have more than one acceptable answer and that they almost never ask procedural questions. It can be stated that asking procedural questions to the students is important in order to be able to plan the lesson, to ensure the participation of the students to the learning process and to be able to evaluate the learning process. The fact that such questions are never asked during the lessons can be interpreted as such that the teachers cannot stay away from being authoritative even though they adopt a student centered educational understanding and that they actually do not give that much of an importance to student opinion.

It was determined that teachers T2 and T3 asked convergent (with a single acceptable answer) questions in almost all observed lessons in addition to divergent (with various possible answers) and evaluation questions. This is thought to be related with the fact that $\mathrm{T} 2$ has been educated at the faculty of sociology prior to the faculty of 
education and that he is well versed in philosophy group of courses. T3 has one more hour of social studies course in comparison with the teachers working at state schools because he works at a private school. He does not experience a problem of time and he works with students who might be considered to be select. That is why, it can be stated that he prefers asking questions that will force them mentally.

$\mathrm{T} 1$ and T4 asked recall and convergent questions more during the lessons. Even though T1 said during the interview, "I really enjoy questions that can force the brains of the children, leading them to make syntheses and interpretations. I pull the question further back so that they can think and make connections thus reaching the point where I want them to reach. So, I sometimes think of it as a mathematical balance, that is I do not see social studies in a strict manner, I don't consider it as straight and structural information; I give importance to synthesis and interpretation in social studies.", it was determined that he actually asks low level questions. This might be caused by the fact that the teacher has been observed in 5th and 6th grade classes because the students in these classes tend to think more concretely and it is more difficult to receive high level responses from these students. However, this can still be interpreted as a problem in reflecting theoretical knowledge to application. T4 works at a school that is ranked last in the high school entrance exams in the district. The student level in the classrooms is very low. However, it was observed that he asks convergent and evaluation questions. Koray and Yaman (2002), Dindar and Demir (2006), Aydemir and Çiftçi (2008), Çolak and Demircioğlu (2010), Kılıç (2010), Kavruk and Çeçen (2013) examined the exam questions prepared by the teachers, whereas Baysen (2006), Can (2006), Bektaş and Şahin (2007), Beskisiz (2009), Khan and Inamullah (2011) examined the questions used by the teachers during the classes. It was concluded as a result of these studies that the exam questions and the questions used during the classes are collected more around the knowledge and comprehension level. The result acquired in this study indicating the fact that teachers mostly ask recall and convergent questions is in accordance with the results of the aforementioned study. However, Çalışkan (2011) concluded as a result of the study carried out that even though social studies teachers still use low level questions during examinations, there is a decrease in the knowledge levels in addition to an increase in the questions at the comprehension, analysis and synthesis, evaluation levels. This is also the case for lessons. There is an increase in the number of high level questions according to the behavioral program, hpowever the rate of asking these questions is still insufficient.

Many questions have been asked during the lessons that were observed during this study. Preparation stage of the lesson is very important in constructivist education understanding and the teachers generally ask questions that test the pre-knowledge levels and whether the students have come to the lesson prepared or not. In addition, the minds of the students are also stimulated thanks to various questions that signify the gains. This stage is very important to ensure that the students are motivated.

In the study, teachers have generally asked partially/sufficient questions during the preparation stage of the lesson. $\mathrm{T} 1, \mathrm{~T} 2$ and T3 asked sufficient number of questions during the introduction stage of the lesson, however it was observed that T4 did not put forth questioning behavior during the preparation stage of the observed lessons. It can be stated as a result of the observed lessons that teachers are not aware of the importance of this section of the lesson or that they neglect it. The reason for this might be due to the lack of knowledge regarding constructivist education understanding or the failure to apply it to the lessons in question.

All four teachers asked the highest number of questions during the learning-teaching period during the observed lessons. The greatest number of questions was asked during this period of the lessons regardless of the method used. All teachers stated during the interviews that questioning is very important and that lessons would not be complete without asking questions. This statement by the teachers overlaps with the study results.

Whereas it was determined that questioning behavior is very low during the conclusion stage of the lessons. Because the conclusion stage was not observed during the lessons. The questions asked during the conclusion stage are also very important. Because they provide information to the teacher about the level of learning attained by the students or whether they learned the information or not. These questions also provide information about whether the topic is understood or nor. The teacher can make an evaluation about the gains and plan the next lesson accordingly using the questions asked at the end of the lessons. Even though the teachers generally approached the students with an understanding of, "is there anything you wish to ask?" either the bell rang or the recording was stopped. Thus, it can be stated that teachers cannot make the lessons more effective and that they experience problems in planning.

It was concluded as a result of the evaluation of the data obtained from observations and interviews that social studies teachers ask simple recall and memory questions and convergent questions with a single acceptable answer which can be classified as low level questions. The teachers also asked evaluation questions to the students but it was determined that divergent questions were asked very rarely and that procedural questions were never asked 
during the lessons. The teachers asked the highest number of questions during the learning-teaching process and the introduction stage of the lessons, whereas questioning behavior was not observed during the conclusion stage of the lessons.

\section{Recommendations}

Based on the study results, the following suggestions can be made to the social studies teachers;

- That they should give importance to asking divergent questions that promote high levels of thinking as well as evaluation questions in addition to simple recall and memory questions and convergent questions which have a single acceptable answer,

- That they should ask more questions which tend to develop creative thinking and problem solving skills,

- That they should focus on asking questions during all stages of the lesson to stimulate pre-knowledge and increase the acquired gain while also giving importance to asking questions at the end of the lessons to measure the learning levels of the students.

The following suggestions can be made to the researchers:

- Increasing the number of studies on how social studies teachers ask questions

- Increasing the number of studies on how students ask questions in the social studies course

- Examining the characteristics of the questions in addition to the strategies of asking questions

- Presenting different educational programs to teachers on asking questions and examining the results of these studies. 


\section{Sosyal Bilgiler Öğretmenleri Nasıl ve Ne Kadar Soru Soruyor?}

\section{Giriş}

Soru sözcüğü Türk Dil Kurumu Sözlüğü’nde (2000) “Bir şey öğrenmek için birine yöneltilen ve karş1lı gerektiren söz veya yazı, sual" olarak tanımlanmaktadır. Bir başka tanıma göre soru, bireyin meraklandırılma yoluyla düşüncesini uyandırma ve bilgi edinimini sağlamak amacıyla oluşturulan, tamamlanmamış, bilgi istemeye dayalı gereksinim ifadelerdir (Akbulut, 1999). Sorular günlük hayatta devamlı kullandığımız sıradan sorulardan uzmanlık gerektiren sorgulamalara varıncaya kadar yaşamın bütün diyaloglarında önemli bir yer teşkil etmektedir (Aydemir ve Çiftçi, 2008). Düşünmeyi ateşleyen bir yöntem olarak kabul edilen soru sorma insanların zihinlerini çalıştırmaları için gereklidir. Öğrenme, sorularla daha anlamlı hale gelir ve düşünme, bir konu üzerinde sorular sorulmaya başlandığı andan itibaren oluşmaya başlar (Özden, 2003). Öğrenme, öğrenenin düşünmeye açık olduğunda ve karşılaşılan sorulara cevaplar bulmaya çalıştığı anlarda daha etkili gerçekleşmektedir. Ancak bu şekilde kalıcı ve anlamlı öğrenmelerin oluşacağı da bir gerçektir. Öğrencilerin zihinsel süreçlerini harekete geçirebilmek ve içinde bulunulan durumla ilgili gerekli sorgulamaları yaptırabilmek için soru sorma çok önemli bir davranış olarak karşımıza çıkmaktadır. Soru sorma düşünmeyi harekete geçiren ve öğrenmeyi sağlayan bir etkinliktir. Soru sorma, öğrencilerin hedeflenen kazanımları ne ölçüde kazandıklarının belirlenmesi için kullanılan en temel araçlardan biridir ve öğretmenlerin öğretme süreçlerindeki en büyük silahı olarak nitelendirilebilir (Çalışkan, 2011).

Gerek düşünmeyi sağlamak gerekse öğrencilerin hedeflenen kazanımları ne ölçüde kazandıklarını tespit edebilmek amacıyla soru sorma bir yöntem olarak eğitimin tüm kademelerinde ve tüm derslerde yoğun bir biçimde kullanılmaktadır. Diğer derslerde olduğu gibi soru-cevap yöntemine yer verilmeyen bir sosyal bilgiler dersi düşünülemez. Tüm konu ve kazanımlarda soru-cevap yöntemi öğrenme-öğretme sürecinin önemli bir kısmını teşkil etmektedir. Öğrencilerin öğrenme-öğretme süreçlerine katılabilmeleri için bu yöntemin yoğun ve bilinçli bir şekilde kullanılması gerektiği söylenebilir. Soru sorma, öğrencileri üst düzey öğrenmelere yöneltmesi bakımından aktif öğrenmede önemli bir yere sahiptir çünkü öğrencinin zihnini aktifleştirir ve aktif düşünmeyi teşvik eder (Ün Açıkgöz, 2014). Öğretmenler, sınıf ortamında etkili öğrenmeyi gerçekleştirmek için iyi soru sorma, problem çözme ve karmaşık düşünmeye yönelik stratejiler geliştirmelidirler. Bir sosyal bilgiler ögretmeninin bu hedefe ulaşabilmesi için öncelikle soru sorma konusunda uzmanlaşması ve farklı soru türleri hakkında bilgi sahibi olması gerekir (Demirkaya, 2011). Öğretmenlerin, soru tipleri ve soruların öğrenci cevaplarına etkileri konusunda bilinçlerinin artması daha etkili bir öğrenmenin gerçekleşmesine katkıda bulunabilir. Farklı soru tipleri, farklı cevaplar gerektirir (Şevik, 2005). Konulara, öğrenme alanlarına ve kazanımlara göre farklı sorular sorulmalıdır. Öğretmen farklı soru türlerini ve bu soru türlerinin öğrenmeye katkısını bildiğinde sorularını buna göre şekillendirecektir. Konuya ve kazanıma göre öğrencilere gerektiğinde hatırlama düzeyinde sorular soracak, gerektiğinde de düşünmeyi teşvik eden üst düzey sorular yöneltecektir.

Sorular çeşitli araştırmacılar tarafından bir takım ölçütler temel alınarak değişik biçimlerde sınıflandırmalara tabi tutulmuştur. Bu sınıflamalarda bazen verilen cevaplar temel alınırken bazen hedefler ya da soru sorma yöntemi dikkate alınmış bazen de sorunun yöneltilme biçiminden hareket edilmiştir. Açıkgöz (2014) soru türlerini tek yanıtlı ve çok yanıtlı olmak üzere ikiye ayırmıştır. Sönmez (2001) ise soru türlerini hedefin düzeyine göre, açık ve kapalı uçlu sorular, yöntemlere göre soru ve yöneltilme biçimlerine göre soru şeklinde sınıflandırmıştır. Kerry (1999) "Etkili Soru Sorma" isimli çalışmasında soruları ayrıntılı bir biçimde analiz etmiş ve dokuz çeşit soru ortaya koymuştur: Hatırlama soruları, isimlendirme soruları, gözlem soruları, kontrol soruları, sahte (takma) sorular, analiz soruları, sentez soruları, değerlendirme soruları, problem çözme soruları (Akt. Büyükalan Filiz, 2004). Tüm bu sınıflamaların yanında soruların düzeylerine göre sınıflanmasında en yaygın olarak kullanılan sınıflama, Bloom ve diğerlerinin (1956) bilişsel alana giren eğitimsel hedefler için yaptıkları bilgi, kavrama, uygulama, analiz, sentez ve değerlendirme basamaklarını içeren aşamalı sınıflamadır. Bu sınıflamada, eğitimsel hedefler ve sorular basitten karmaşığa doğru dizilirler. Buna göre, en basit hedefler/sorular bilgi, en karmaşık hedefler/sorular ise değerlendirme düzeyinde yer alırlar (Açıkgöz, 2003). Bir diğer sınıflama ise bu araştırmada da kullanılmış olan öğretmen sorularının hangi kategoride incelenebileceğine ilişkin Selçuk (2001) tarafından yapılan sınıflamadır. Bu sınıflamada sorular; basit hatırlama ve bellek soruları, yakınsak sorular (kabul edilebilir tek cevabı olan sorular), ıraksak sorular (birkaç muhtemel cevabı olabilecek sorular), değerlendirme soruları (yargı bildiren sorular) ve işleyişle ilgili sorular (organizasyon, disiplin ve dersin yapısııla ilgili sorular) şeklinde beş kategoriden oluşmaktadır. Basit hatırlama ve bellek soruları ile yakınsak (kabul edilebilir tek cevabı olan sorular) soru türleri belirli cevaplar gerektirdiği için alt düzeyli sorular olarak nitelendirilebilir. Öğrencilerin bu tür soruları cevaplarken çok fazla düşünmesine gerek yoktur. Iraksak sorular ve değerlendirme soruları ise farklı cevaplar gerektirebileceği için öğrencilerin zihinsel anlamda sınırlarını zorlayan ve üst düzey düşünmelerini sağlayan türde 
sorular olarak ifade edilebilir. Öğrencilerin düşünme düzeyleri, öğretmenin sorduğu sorulardan etkilenir. Eğer öğrenciler düşük düzeyli sorularla karşılaşırlarsa düşük düzeyli düşünme eğilimine girerler. Eğer öğrencilere üst düzey bilişsel düzeyde sorular sorulursa daha yaratıcı ve çok yönlü düşünmeye yatkın olacaklardır. Araştırmalar, öğretmenlerin sorduğu soruların çoğunluğunun düşük seviyeli, kitaba bağlı ve basit cevaplı sorular olduğunu göstermiştir (Selçuk, 2001). Soruların sınıflandırılması sınıf doğasının anlaşılmasına katkıda bulunur, çünkü farklı soru tipleri farklı cevaplar gerektirir. Örneğin, sınıf içerisinde sorulan sorular incelendiğinde, alt-seviyeli sorular çok fazla ise ve üst-seviyeli soru hemen hemen hiç sorulmamışsa burada bir sorun olabilir. Çünkü öğrencilerin düşünme ve konuşma becerileri sınırlandırılmış olur. Bunu fark eden bir öğretmen bir sonraki ders planını hazırlarken her iki soru tipini de kullanarak daha dengeli bir plan yapabilir. Dolayısı ile her iki soru tipi de farklı zamanlarda, farklı hedefler için gerekli olmaktadır. Etkili öğrenme ise farklı soru tipleri ayrı ayrı değil, birlikte kullanıldıkları zaman meydana gelir (Şevik, 2005). Sonuç olarak soru türleri hakkında bilinçli olan bir öğretmenin bu yöntemi çok daha etkili biçimde kullanacağı söylenebilir.

Ders işleme sürecinde sorulan soruların türleri ile birlikte sorulan soru miktarı ve bu soruların dersin hangi bölümünde sorulduğu da önemli bir konudur. Öğretmenler dersin giriş, öğrenme-öğretme ve değerlendirme süreci gibi belirli bölümlerinde çeşitli sorular sormaktadırlar. Şevik'in (2005) aktarımına göre olağan bir okul gününde öğretmenler birçok soru sorarlar. Yapılan araştırma sonuçlarına göre okuldaki bir günün beşte dördünün sorucevap metoduyla geçtiğini söylemek mümkündür (Gall, 1970; Stevens, 1912). Kerry (1998) öğretmenlerin ders başına 43,6 soru sorduğunu ve ortalama bir kariyer sonunda ise 1,5-2 milyon soruya ulaşabildiklerini söylemektedir. Ders işleme sürecinde sorulan soruların miktarı kadar hangi bölümde ne kadar soruya yer verildiği hususu da önemlidir. Öğretmenlerin sınıf içi ders işleme süreçlerinde sormuş oldukları sorular pek çok boyutuyla teorik ve uygulama alanında zengin veriler oluşturmaktadır. Bu araştırmanın da sosyal bilgiler öğretmenlerinin sınıf içi ders süreçlerindeki sormuş oldukları soruların düzeyi ve miktarı gibi ölçütler açısından birlikte değerlendirilerek var olan durumun betimlenmesiyle alana katk1 sağlayacağı düşünülmektedir. Yine bu araştırmadan elde edilecek bulguların eğitim-öğretimimizdeki eksikliklerin giderilmesi noktasında, başta sosyal bilgiler öğretmenleri olmak üzere, fakültelerin öğretmen yetiştiren bölümleri ile sınıf içi ders işleme süreçlerinde başarı ve verimliliği arttırma amacında olan araştırmacı ve uygulamacılara faydalı olacağı söylenebilir.

$\mathrm{Bu}$ araştırmada, sosyal bilgiler öğretmenlerinin sınıf içi ders işleme süreçlerindeki sormuş oldukları soruların düzeyini ve miktarını incelemek ve örneklerle betimleyerek yorumlamak amaçlanmıştır. Bu amaç çerçevesinde şu sorulara cevap aranmıştır:

- Sosyal bilgiler öğretmenlerinin sınıf içi ders işleme süreçlerinde sordukları soruların düzeyleri nasıldır?

- Sosyal bilgiler öğretmenlerinin sınıf içi ders işleme süreçlerinde sordukları sorunun miktarı nedir?

\section{Yöntem}

\section{Araştırmanın Modeli}

Araştırmada nitel araştırma desenlerinden durum çalışması deseni kullanılmıştır. Durum çalışması nasıl ve niçin sorularını temele alan, araştırmacının kontrol edemediği bir olgu ya da bir olayı derinlemesine incelemeye imkân sağlayan bir araştırma çeşididir (Yıldırım ve Şimşek, 2011). Glesne'ye (2013) göre ise durum çalışması bir olayın ya da bir durumun yoğun bir biçimde çalışılmasını ifade etmektedir. Durum çalışmasında belirli bir durumun derinlemesine incelenmesi ve detaylı sonuçların çıkarılması amaçlanmaktadır (Köse, 2010). Bu araştırmada öğretmenlerin soru sorma süreçleri detaylı bir şekilde incelenmiş ve bu durum araştırma sonuçlarına yansıtılmaya çalışılmıştır. Araştırma sürecinde katılımcı öğretmenlerle birebir görüşmeler yapılmış, gözlem süreleri uzun tutulmaya çalışılmış ve gözlemlerin yapıldığı günlerde öğretmenlerle mümkün olduğunca vakit geçirilmeye özen gösterilmiştir. Bu sayede öğretmenler hakkında detaylı bilgiler edinme imkânına sahip olunmuş ve araştırılan konu derinlemesine incelenmiştir.

\section{Çalışma Grubu}

Araştırma grubu Sakarya ili Erenler ve Serdivan ilçelerinde 2013-2014 eğitim ve öğretim yllında görev yapan Sosyal Bilgiler öğretmenlerinden oluşmaktadır. Çalışmaya katılan öğretmenlerin belirlenmesinde amaçlı örneklem yöntemlerinden kolay ulaşılabilir durum örneklemesi tercih edilmiştir. Kolay ulaşlabilir durum örneklemesinde araştırmacı, yakın olan ve erişilmesi kolay bir durumu seçer ki bu da araştırmaya hız kazandıran bir durumdur. $\mathrm{Bu}$ yüzden de nitel araştırmalarda yaygın olarak kullanılmaktadır (Yıldırım ve Şimşek, 2011). Pilot uygulamayla birlikte araşıtırmada toplam beş sosyal bilgiler öğretmeni gönüllülük esasına göre katılımcı olarak yer almıştır. Araştırmaya katılan öğretmenlerin özellikleri Tablo 1'de gösterilmiştir. 


\begin{tabular}{llllll}
\hline \multicolumn{2}{l}{ Tablo 1. } \\
\multicolumn{2}{l}{ Araştırmaya Katılan Öğretmenlerin Özellikleri } & \\
\hline Katılımcılar & Cinsiyet & Yaş & $\begin{array}{l}\text { Mesleki Kıdem } \\
(\text { Y1l) }\end{array}$ & $\begin{array}{l}\text { Görev Yaptığ1 } \\
\text { Kurum }\end{array}$ & $\begin{array}{l}\text { Mezuniyet } \\
\text { (Lisans) }\end{array}$ \\
\hline Ö1 & Kadın & 43 & 20 & Devlet okulu & Fen-Edebiyat F. \\
Ö2 & Erkek & 40 & 12 & Devlet Okulu & Eğitim Fakültesi \\
Ö3 & Kadın & 29 & 7 & Özel Okul & Eğitim Fakültesi \\
Ö4 & Erkek & 41 & 13 & Devlet Okulu & Fen-Edebiyat F. \\
\hline
\end{tabular}

Araştırmaya katılan öğretmenler Ö1, Ö2, Ö3 ve Ö4 olarak kodlanmıştır. Araştırmada yer alan Ö1, 43 yaşında bir kadındır. Fen-Edebiyat Fakültesi Tarih mezunu olup 20 yıldır öğretmenlik yapmaktadır. Ö2, 40 yaşında bir erkektir. Eğitim Fakültesi Sosyal Bilgiler Öğretmenliği mezunu olup 12 yıldır öğretmenlik yapmaktadır. Ö3, 29 yaşında bir kadındır. Eğitim Fakültesi Sosyal Bilgiler Öğretmenliği mezunu olup 7 yıldır öğretmenlik yapmaktadır. Ö4, 41 yaşında bir erkektir. Fen-Edebiyat Fakültesi Tarih mezunu olup 13 yıldır öğretmenlik yapmaktadır.

\section{Veri Toplama Araçları}

Araştırmada, araştırmacılar tarafından geliştirilen "gözlem formu" ve "görüşme formu" ile birlikte "video kayıtları" veri toplama aracı olarak kullanılmıştır.

Gözlem Formu: Öğretmenlerin ders işleme süreci esnasında sormuş olduğu soruların düzeyi benzer çalışmalardan yararlanılarak oluşturulan gözlem formu kullanılarak incelenmiştir. Gözlem formu hazırlanırken öncelikle Selçuk'un (2001) çalışması incelenerek sorulan soruların düzeyini ve miktarını tespit etmeye yönelik bir form oluşturulmuştur. Taslak niteliğinde hazırlanan gözlem formu, daha önce bu konu alanında çalışması olan akademisyenlerden oluşan dört uzman tarafından incelenmiştir. Bu uzmanların formu içerik, anlaşılırlık, görünüş açısından değerlendirilmiş ve onlardan gelen dönütler dikkate alınarak yapılan gerekli düzeltme, ekleme ve çıkarma işlemleri sonrasında gözlem formu son şeklini almıştır. Uzman görüşlerine göre araştırmacılar tarafından yapılandırılan sekiz maddelik gözlem formu iki bölümden oluşmaktadır. Birinci bölüm, soruların düzeyini belirlemek için Selçuk'un (2001) yapmış olduğu; basit hatırlama ve bellek soruları, yakınsak sorular (kabul edilebilir tek cevabı olan sorular), ıraksak sorular (birkaç muhtemel cevabı olabilecek sorular), değerlendirme soruları (yargı bildiren sorular) ve işleyişle ilgili sorular (organizasyon, disiplin ve dersin yapısıyla ilgili sorular) şeklindeki sınıflamanın yer aldığı beş kategorilik bölümdür. Bu bölümde "hiç", "kısmen”, "çok” şeklinde üçlü derecelendirme kullanılmış ve bu formada davranışın gözlenemediği maddeler "hiç", gözlendiği maddeler "kısmen" ve "çok” olarak değerlendirilmiştir. İkinci bölüm ise "derse hazırlık, öğrenme-öğretme süreci ve dersin sonu" aşamalarında öğretmenlerin ders işleme sürecinde sormuş oldukları soru miktarını belirlemeye yönelik oluşturulan üç maddelik bölümdür. Bu bölümde "hiç", "1-4 soru” ve "daha fazla" olarak derecelendirilerek değerlendirilmiştir. Ayrıca anekdot kaydı yapılabilmesi için gözlem formunda her bir maddenin yanında "açıklama" bölümü yer almıştır. Formun başında bu gözlem formunun öğretmenlerin sorduğu soruların düzeyi ve miktarını ölçmeyi amaçlayan bir yapıya sahip olduğunu açıklayan bir de yönergeye yer verilmiştir.

Görüşme Formu: Araştırma kapsamında öğretmenlerin soru sorma süreçlerine ilişkin görüş ve düşüncelerini öğrenmek amacıyla araştırmacılar tarafından denemelik sorular yazılmış ve bu sorular, dört alan uzmanı tarafından incelenmiştir. Uzmanlar taslak soruları kapsam, görünüş ve anlaşılırlık bakımından incelemişlerdir. Uzman görüş ve önerileri doğrultusunda gerekli değişikliklerin yapılmasıyla form son şeklini almıştır. Öğretmenlerin soru sorma süreçlerine ilişsin görüş ve düşüncelerini belirlemeye yönelik hazırlanmış olan görüşme formunda öğretmenlerin derslerin hangi bölümünde soru sorduklarına ilişkin bir soru bulunmaktadır ve araştırma kapsamında bu soru ele alınmıştır. Gözlemlerden sonra öğretmenlerle soru sorma süreçleri hakkında görüşmeler yapılmış ve bu görüşmeler ses kayıt cihazıyla kaydedilmiş ve daha sonra araştırmacılar tarafından deşifre edilmiştir.

Video Kayıtları: Araştırmada verileri toplamada ve analiz sürecinde kolaylık olması için gözlem yapılan dersler kamera ile kayıt altına alınmıştır. Sürecin kayıt altına alınmasından önce kurumlardan ve araştırmaya katılan öğretmenlerden gerekli izinler alınmıştır. Araştırmacılardan biri tüm derslere öğretmenlerle birlikte katılmış ve sınıf ortamındaki doğallığı bozmamaya çalışarak tüm dersleri kamera ile kayıt altına almıştır. Gözlem yapılan tüm 
dersleri içeren toplam 32 ders saatinden oluşan video kayıtlarının tamamı araştırmacılar tarafindan yazıya geçirilmiştir.

\section{Geçerlik ve Güvenirlik}

$\mathrm{Bu}$ çalışmada geçerlik ve güvenirliğin sağlanabilmesi için bazı stratejilere başvurulmuştur. İnandırıcılı̆̆ (iç geçerlik) sağlayabilmek adına uzun süreli etkileşim, derinlik odaklı veri toplama, çeşitleme, uzman incelemesi ve katılımcı teyidi gibi yöntemler önerilmektedir (Yıldırım ve Şimşek, 2011). Bu araştırmada da inandırıcılığın sağlanabilmesi için araştırma süresi uzun tutulmaya çalışılmış, veri toplama yöntemi olarak da gözlem ve görüşme yöntemleri bir arada kullanılmıştır. Ayrıca araştırmacı çeşitlemesine gidilerek analiz sürecinin iki araştırmacı tarafından ayrı ayrı yapılması sağlanmış ve sonuçlar karşıllaştırılmışıtır. Veri toplama araçları olarak kullanılan gözlem ve görüşme formları alan uzmanları incelemesine sunularak uzman görüşü alınmıştır. İnandırıcılığı sağlama adına uygulanan bir yöntem de katılımcı teyididir. Bu yöntemde çözümlenen verilerin sağlandığı ya da görüş̧e yapılan kişilerden bulgulara iliş̧in geribildirim istenmektedir (Merriam, 2013). Bu çalışmada da veriler yazıya geçirilip çözümlendikten sonra katılımcılara gösterilmiş ve bu şekilde katılımcı doğrulaması gerçekleştirilmiştir.

Araştırma sonuçlarının aktarılabilirliğini arttırmak için ayrıntılı betimleme ve amaçlı örnekleme yapılması önerilmektedir (Yıldırım ve Şimşek, 2011). Bu amaçla araştırma sürecinde elde edilen veriler ayrıntılı biçimde sunulmuş ve doğrudan alıntılarla desteklenmeye çalışılmıştır.

\section{Uygulama Süreci}

Öncelikle araştırmanın amacı bağlamında pilot çalışma yapmak için bir sosyal bilgiler öğretmeni altı ders saati gözlemlenmiş ve bu gözlemler kamera ile kayıt altına alınmıştır. Araştırma için gerekli olan veri toplama araçlarının geliştirilmesi sürecinde bu kayıtlardan yararlanılmış ve araştırmanın süreci planlanırken bu pilot uygulama dikkate alınmıştır. Ayrıca veri toplama süreci öncesinde araştırmaya katılacak olan öğretmenler ve okul idareleri ile görüşme yapılıp gerekli izinler alınmıştır. Araştırma için gönüllü öğretmenler seçilerek öğretmenlere süreç ile ilgili bilgiler verilmiş ve gözlemci etkisini giderebilmek amacıyla kayıt süresi uzun tutulmaya çalışılmıştır. Daha sonra 2013-2014 eğitim ve öğretim yılının birinci döneminde dört haftalık süreç içerisinde araştırma grubunu oluşturan sosyal bilgiler öğretmenlerinin her biri toplam sekiz ders saati boyunca gözlemlenmiş, gözlem esnasında gözlem formları işlenmiş ve aynı zamanda tüm bu süreç kamera ile kayıt altına alınmıştır. Gözlem ve ders kayıtlarının sonrasında araştırmaya katılan öğretmenlerle öğretmenlerin soru sorma süreçlerine ilişkin görüş ve düşüncelerini tespit etmeye yönelik hazırlanmış olan "Görüşme Formu" doğrultusunda görüsşmeler yapılmış ve görüşmeler ses kayıt cihazı ile kaydedilmiştir. Son olarak ise gözlem, görüşme ve video kayıtlarından elde edilen veriler analiz edilmişsir.

\section{Verilerin Analizi}

Araştırmadan elde edilen veriler betimsel analiz yöntemiyle çözümlenmiştir. Betimsel analiz yönteminde elde edilen veriler, daha önceden belirlenen temalara göre özetlenip yorumlanır. Betimsel analizde görüşülen ya da gözlenen bireylerin görüşlerinin çarpıcı biçimde yansıtılabilmesi için doğrudan alıntılara sıklıkla yer verilir. Bu tür analizde amaç elde edilen bulguların düzenlenmiş ve yorumlanmış biçimde sunulabilmesidir (Yıldırım ve Şimşek, 2011). Bu doğrultuda öncelikle gözlem ve görüşmeler sonrasında elde edilen tüm video kayıtları ve görüşme ses kayıtları deşifre edilmiştir.

Araştırmanın katılımcı grubunu oluşturan dört öğretmenin her bir dersinde davranışların varlığı araştırmacılardan biri tarafından teker teker gözlenmiş ve araştırma kapsamında hazırlanmış olan gözlem formuna kaydedilmiştir. Yine bu formdan elde edilen verilerin güvenirliğini arttırmak için video kayıtları kullanılarak ikinci bir araştırmacının da aynı işlemleri tekrar etmesi sağlanmıştır. Gözlem süreci sona erdiğinde gözlem formlarındaki davranışları gösterme sıklığının ortalaması alınmıştır. Gözlemlerden elde edilen bulgulara doğrudan alıntılar eklenerek analizlerin örneklendirilmesine çalışılmıştır. Görüşmelerden elde edilen veriler de araştırmanın bulgularının desteklenmesinde kullanılmıştır.

\section{Bulgular}

Ö1, altınc1 sınıflarda "Yeryüzünde Yaşam" ve beşinci sınıflarda "Adım Adım Türkiye" üniteleri işlenirken sekiz ders saati; Ö2, yedinci sınıflarda "Ülkemizde Nüfus" ünitesi işlenirken sekiz ders saati; Ö3, altıncı sınıflarda "Yeryüzünde Yaşam", yedinci sınıflarda "Ülkemizde Nüfus" ünitesi işlenirken sekiz ders saati; Ö4, altınc1 sınıflarda "Yeryüzünde Yaşam" ve yedinci sınıflarda "Türk Tarihinde Yolculuk" üniteleri işlenirken sekiz ders saati gözlemlenmişlerdir. İki ders saati üst üste yapılan sınıflarda konu bütünlüğünü bozmamak için bir tek gözlem formu tutulmuştur. Ö1 için altı adet, Ö2 için dört adet, Ö3 için dört adet ve Ö4 için altı adet gözlem formu 
tutulmuştur. Tüm bu öğretmenlerle gözlemler tamamlandıktan sonra araştırmanın amacı kapsamında görüşmeler yapılmıştır. Öğretmenlerden gözlem, görüşme ve video kayıtları aracılığıyla elde edilen verilerin çözümlenmesi neticesinde ortaya çıkan bulgulara aşağıda yer verilmiştir.

\begin{tabular}{l} 
Tablo 2. \\
Sosyal Bilgiler Derslerinde “Ö1” Tarafindan Sorulan Soruların Düzeyine İlişkin Bulgular \\
\hline \\
Soruların düzeyi
\end{tabular}

Ö1 gözlemlenen derslerde öğrencilere sıklıkla basit hatırlama ve bellek soruları ile yakınsak yani kabul edilebilir tek cevabı olan sorular yöneltmiştir. Değerlendirme düzeyinde sorular da sorduğu görülmüş ancak rraksak yani birkaç muhtemel cevabı olabilecek ve de işleyişle ilgili sorular sormadığı gözlemlenmiştir. Ö̉ kendisiyle yapılan görüşmede sorduğu soruların düzeyi ile ilgili olarak şunları söylemiştir:

"Ben çocukların beynini yorabileceği, sentez yapabileceği ve yorum yapabileceği sorularl çok seviyorum. Çocuklar hani kafa yorsunlar oradan bağlantı kurarak istediğim noktaya getirebilmek için soruyu daha gerilere çekebiliyorum. Yani matematiksel bazen matematiksel denge gibi düşünüyorum hani sosyal bilgileri şey olarak düşünmüyorum moda mod, düz direkt kalıpsal bilgiler olarak düşünmüyorum sosyal bilgilerde sentez ve yoruma çok önem veriyorum."

Ö1'in sorduğu soruların düzeyi ile ilgili ifadeleri gözlem sonuçlarıyla çelişmektedir. Ö1'in çoğunlukla öğrencilere basit hatırlama ve bellek soruları ile yakınsak düzeyde sorular sorduğu, üst düzey düşünmeyi gerektirecek tarzda soruları ise yeteri kadar sormadığı görülmüştür.

Elde edilen bu bulgulara kanıt olabilecek soru düzeylerini yansıtan soru-cevap diyalog örnekleri aşağıda verilmiştir.

Ö1: Evet soruyorum. Olgu nedir? Bir olgu cümlesi istiyorum. (tekrarlar ve kavramı tahtaya yazar)

Ö̆̆renci: Olgu herkesçe kabul edilen bilimsel araştırmalara dayanılan nasıl diyeyim... Bilimsel araştırmalara dayanılan...

Ö1: Herkesçe kabul edilen doğruluğu herkesçe kabul edilen bilimsel araştırmalar sonucu bulunan ya da ispatlanan cümlelerdir bilgilerdir.

Bu diyalogda geçen soru basit hatırlama ve bellek sorusu olduğu görülmektedir. Çünkü öğretmen burada bir tanım sormakta ve bu soruya ilişkin bir örnek istemektedir.

Ö1: Evet (ögrencinin adını söyler)söyle bakalım?

Öğrenci: Neyi?

Ö1: Neyi? Öğrenci olarak senin sorumluluğun ne?

Ö ̆grenci: Ögrenci olarak benim sorumluluğum okul kurallarına uymak

Ö1: Başka?

Ögrenci: Okul faaliyetlerine katılmak

$\mathrm{Bu}$ diyalogda geçen soru yakınsak soru (kabul edilebilir tek cevabı olan sorular) olarak değerlendirilebilir. Öğretmen burada bir öğrencinin ne tür sorumlulukları olduğunu sormaktadır. Bu soruya verilebilecek cevaplar bellidir o yüzden de yakınsak soru olarak kabul edilebilir. 
Tablo 3.

Sosyal Bilgiler Derslerinde "Ö1”in Ders Sürecindeki Soru Miktarına İlişkin Bulgular

\begin{tabular}{|c|c|c|}
\hline Ders sürecindeki soru miktarı & 关 & 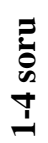 \\
\hline 1- Derse hazırlık aşaması & 3 & 2 \\
\hline 2- Öğrenme-öğretme süreci aşaması & - & - \\
\hline 3- Dersin son aşaması & 6 & - \\
\hline
\end{tabular}

Sınıf içi yapılan gözlemlerde öğretmenin derse hazırlık aşamasında daha az soru sorduğu ancak öğrenme-öğretme süreci esnasında daha fazla soru sorduğu belirlenmiştir. İzlenen derslerde ise sonuç bölümü gözlemlenememiş genelde öğrenme-öğretme süreci esnasında zil çalmış ya da kayıt sona ermiştir.

Ö1 soru sorma süreçleri hakkında gözlemler bittikten sonra yapılan görüşmede derslerde sorulara ne kadar yer verdiğine ilişkin şunları söylemiştir:

"Bu süre her zaman aynı olmuyor. Konuya göre değişebiliyor. Konunun içeriğine göre değişebiliyor. Sınıfların seviyesine göre de değişebiliyor benim için. Yani ĕger şeyse sinıfin seviyesi güzelse orda direkt soruyla başlayabilirim. Onlarda belli bir birikim olduğunu biliyorum ya ama seviye düşükse onda önce konuyu anlatıp ben konuyu onlara duyurup sonra soru sormayl tercih ediyorum. Biz eski ögretmenlerde 15-20 yllı aşmış ögretmenlerde genelde ortada ve sonda oluyor. Ama eğitim sisteminde başta, her yerde soru sorulabiliyor. Benim tarzım şu ben ögrenciye bilgiyi yüklemeden onu o konuyla bir anlatmadan doyurmadan soru sorma taraftar değilim. Çünkü çocuklar her zaman hazırlıklı gelmiyorlar. Direkt ben başta soru sordum sadece güncel hayatta işte karşılaştıkları kadarıyla cevap verebilir ama teknik olarak, terimsel olarak veremiyorlar."

Ö1 kendisiyle yapılan görüşmede derslerinde soruları en fazla ortada ve sonda sorduğunu ifade etmiştir. Gözlem sonuçlarına bakıldığında ise Ö1'in derse genellikle soru sorarak başladığı ancak soruları en çok öğrenme-öğretme süreçleri esnasında sorduğu gözlemlenmiştir. Bu durum Öl'in görüşmedeki ifadelerini desteklemektedir. Öğretmenin dersin bitiminde soru sorduğuna ilişsin ifadesi ise gözlem bulgularıyla çelişmektedir.

\section{Tablo 4.}

Sosyal Bilgiler Derslerinde “Ö2” Tarafından Sorulan Soruların Düzeyine İlişkin Bulgular

\begin{tabular}{lccc} 
Soruların düzeyi & & 2 & 2 \\
& & - & 3 \\
\hline 1- Basit hatırlama ve bellek soruları sorar. & - & - & 4 \\
2- Yakınsak sorular: Kabul edilebilir tek cevabı olan sorular sorar. & - & 1 & 2 \\
3- Iraksak sorular: Birkaç muhtemel cevabi olabilecek sorular sorar. & 4 & - & - \\
4- Değerlendirme soruları: Yargi bildiren sorular sorar. & & \\
5- Issleyişle ilgili sorular: Organizasyon, disiplin ve dersin yapisılyla ilgili sorular & 4 \\
sorar. & & \\
\hline
\end{tabular}

Öğretmen gözlemlenen derslerde öğrencilere sıklıkla ıraksak yani birkaç muhtemel cevabı olabilecek sorular yöneltmiş ayrıca yeterli düzeyde hatırlama ve bellek soruları, yakınsak sorular ve değerlendirme soruları sormuştur. İşleyişle ilgili soru sorulmamıştır.

Elde edilen bu bulgulara kanıt olabilecek soru düzeylerini yansıtan soru-cevap diyalog örnekleri aşağıda verilmiştir.

Ö2: Peki, gecekondu evlerinde yaşayan insanlar göçlerin sonuçlart itibariyle ne tür sıkıntılarla karşılaşırlar?

Öğrenci: Hocam doğa zarar görüyor, yeşillikler azallyor. 
Ö2: Göçlerin sonuçları içerisindedir evet. Gecekondular rasgele yapıldığı için mesela yeşil alanlar azallyor. Evet? Öğrenci: Elektrik, su gibi imkânlar azalır Hocam

Bu diyalogda öğretmen göçlerin ne gibi sonuçları olduğunu sormaktadır. Bu soruya verilebilecek cevaplar bellidir o yüzden de yakınsak soru olarak kabul edilebilir.

Ö2: Peki şunu söyleyeyim, biz bu insanları Birleşmiş Milletler Kriterleri'ne göre 65 yaş üstü insan tüketici nüfus ise de, artık bunları şu şekilde mi düşünüyoruz; hiç bir işe yaramayan, tamamen oturduğu yerde tüketen insanlar gözüyle mi bakıyoruz? Ya da öyle mi bakmamız gerekir? (bekler) Evet?

Öğrenci: Öyle bakmamamız gerekir hocam, zaten onlar 18-64 yaş arasında onlar da çalışmışlardır. Bu yüzden o gözle bakmamallyı.

Ö2: Tamam bir zamanlar onlar da üreten insanlardl. Küçükler tüketen insanlardı onlar çalışstlar. Peki başka? Mesela 64 yaşındaki 65 yaşındaki bir mühendis, bir mimar veya siyasetçi veya hukukçu ya da doktor ya da sporcu. Insanlar bunlardan yararlanamaz mı? Biz bunların yani hiçbir şeyinden yararlanamaz miyız?

Öğrenci: Yararlanirlz

Ö2: Peki, nasll, neyinden yararlanacă̆lz?

Öğrenci: Tecrübelerinden Hocam

Ö2: Hayat tecrübelerinden yararlanacă̆ız değil mi? Bakın bazen insanların iş yapması demek ille de kalkı o tarafa bu tarafa koşturması, fabrika ya da inşaatta çalışması demek değildir. Yerine göre o insanların tecrübeleri vardır, hayatta pek çok olaylar karşılaşmış̧lardır. Bizim yaşadıklarımıza benzer şeyler yaşamışlardır. Biz de onların hayat tecrübelerinden faydalanmalyyı, tamam mı? Bu anlamda büyükler bir toplumun zihin yapısını oluşturur.

Bu diyalogda öğretmen öğrencilere 65 yaş üzeri nüfusu nasıl değerlendirmemiz gerektiği sorusunu yöneltmiştir. $\mathrm{Bu}$ konuda farklı bakış açıları olabileceği gibi yorum gerektirmesi sebebiyle bu soru raksak (birkaç muhtemel cevabı olabilecek soru) olarak değerlendirilebilir.

Ö2: Kimler İstanbul'a gitti? (Bir öğrenciye söz verir) İstanbul'a gittiğin zaman İstanbul şehriyle ilgili izlenimin nelerdir, izlenimlerin nelerdi mesela? O şehir hakkında ne düşünüyorsun?

Ö̈rrenci: Hocam adım atacak yer yok.

Ö2: Adim atacak yer yok

A.Ö.: Hocam nüfusu o kadar çok ki hem alan da dar

Ö2: Nüfusu çok kalaballk bir şehir olarak gözüne çarptı

A.Ö.: Evet Hocam sanayi ve ticaret çok gelişmiş. Hastaneler falan çok gelişmiş

$\mathrm{Bu}$ diyalogda öğretmen öğrenciye İstanbul şehri hakkındaki izlenimlerini, düşüncelerini sormaktadır. Değerlendirme yapmasını istediği için yargı bildiren bir soru olarak değerlendirilebilir.

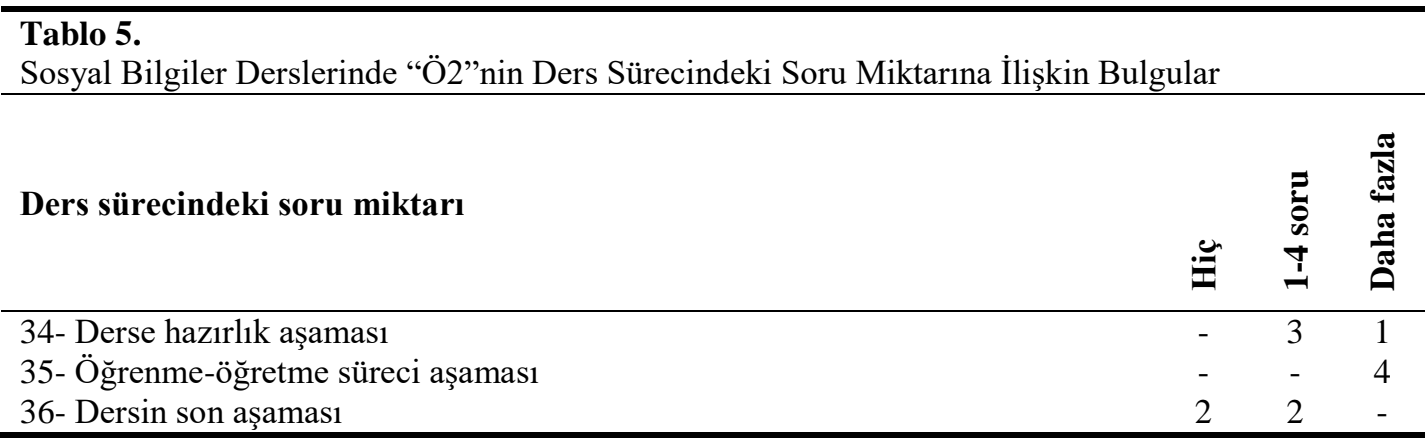

Gözlem sonuçlarına göre Ö2 derse sorularla başlamış ve en çok soruyu öğrenme-öğretme süreçleri esnasında sormuştur. İzlenen derslerde sonuç bölümü gözlemlenmemiş genelde öğrenme-öğretme süreci esnasında zil çalmış ya da kayıt sona ermiştir. Ö2 soru sorma süreçleri hakkında gözlemler bittikten sonra yapılan görüş̧mede derslerde sorulara ne kadar yer verdiğine ilişkin şunları söylemiştir:

"Şimdi ilk olarak dersin daha birinci dakikasında öğrencinin hazır bulunuşluk seviyesini ölçmek ve öğrencinin tamamen derse odaklanmasını sağlamak amacıyla zaten konuyu anlatmadan derste soru sorarak başlyyorum. Belli bir süre sonra yani öğrenci ilk on dakikada öğrencinin dikkat seviyesi maksimum seviyededir. Onuncu dakikadan 
itibaren öğrencinin dikkati yavaş yavaş dă̆lmaya... Dersin onuncu ve yirminci dakikası arasında birer ikişer soru soruyorum. Mutlaka soru sorarken de farklı gruplardan olmasına kı-erkek ögrenci arasında da bir ayrım yapmaya çalışlyorum. Yirminci dakikasından sonra işte araya mesela kısa bir tekrar yapıyorum. O tekrarın ardından konuyu anlayıp anlamadıklarını ilk yarım saat içerisinde soruyorum. Ve en son dersin bitmesine birkaç dakika kala bu sefer dersin genelinin içinde anlattı̆̆ım konulardan sorular sormaya çalışıyorum”.

Ö2 kendisiyle yapılan görüşmede derse soru sorarak başladığını, ilerleyen süreçte de sorular sorduğunu ve dersin bitmesine yakın anlattığı konulardan sorular sormaya çalıştığını ifade etmiştir. Gözlem sonuçlarına bakıldığında ise Ö2'nin derse genellikle soru sorarak başladığı ancak soruları en çok öğrenme-öğretme süreçleri esnasında sorduğu gözlemlenmiştir. Bu durum Ö2'nin görüşmedeki ifadelerini desteklemektedir. Öğretmenin dersin bitiminde soru sorduğuna ilişkin ifadesi ise gözlem bulgularıyla çelişmektedir.

\begin{tabular}{l} 
Tablo 6. \\
Sosyal Bilgiler Derslerinde “Ö3” Tarafından Sorulan Soruların Düzeyine İliş̧kin Bulgular \\
\hline \\
Soruların düzeyi
\end{tabular}

Öğretmen gözlemlenen derslerde öğrencilere sıklıkla basit hatırlama ve bellek soruları ile yakınsak sorular yani kabul edilebilir tek cevabı olan sorular yöneltmiş ayrıca yeterli düzeyde ıraksak ve değerlendirme düzeyinde sorular sormuştur. İşleyişle ilgili soru sorulmamıştır.

Elde edilen bu bulgulara kanıt olabilecek soru düzeylerini yansıtan soru-cevap diyalog örnekleri aşağıda verilmiştir.

Ö3: Dünya üzerindeki iklimleri ögrenmiştik. Bunlar nelerdi? Kim sıralayacak? (Öğrencinin adını söyler)

Ö ̆̆renci: Muson iklimi, kutup iklimi, çöl iklimi, ılıman iklim

$\mathrm{Bu}$ diyalogda öğretmen burada dünyada görülen iklimlerin neler olduğunu sormuştur. Bu basit hatırlama ve bellek düzeyinde bir soru olarak değerlendirilmiştir.

Ö3: Peki, mesela şöyle bir şey soracă̆ım. Ülkenin doğusunda yapılabilecek ekonomik faaliyetler sence neler?

Ögrenci: Hayvancilık.

Öğretmen burada ülkemizin belli bir bölümünde ne gibi ekonomik faaliyetler yapılabileceğini sormaktadır. Bu soruya verilebilecek cevaplar bellidir o yüzden de yakınsak soru olarak kabul edilebilir.

Ö3: Sormak istediğim şey şu: “İstanbul'un taşı topră̆ altın” ne demek?

Öğrenci: Istanbul'da daha çok iş var para kazanabiliriz.

Ö3: Istanbul'da çok is var para kazanabiliriz. Başka?

B.Ö: Hocam İstanbul'un taşından da toprağından da bir bölüm çıkarabiliriz.

Ö3: Nasil?

A.Ö: Taşını alır betona dönüştürürüz. Toprağını alır tarıma dönüştürürüz (gülüşmeler)

Ö3: Bu da değişik bir yorum. Bir daha tekrarlar mısın?

A.Ö: Taşını alır betona dönüştürürüz. Toprağını alır tarıma dönüştürürüz

Bu diyalogda öğretmen İstanbul hakkındaki bir deyişten yola çıkarak öğrencilerin yorum yapmasını istemiştir. Farklı cevaplar verilebilecek bir soru olduğu için ıraksak düzeyde değerlendirilmiştir. 
Ö3: Evet, üniversite sinavina girmeden ne yapacaklardl? Devlet üniversitesinde okuyabileceklerdi. Peki, bununla ilgili herhangi bir düşüncesi olan var mı?

Ö3 Suriye'den Türkiye'ye zorunlu olarak göç edenlere ülkemizin destek olmasıyla ilgili öğrencilerin görüşünü sorduğu için değerlendirme (yargı bildiren) bir soru olduğu görülebilir.

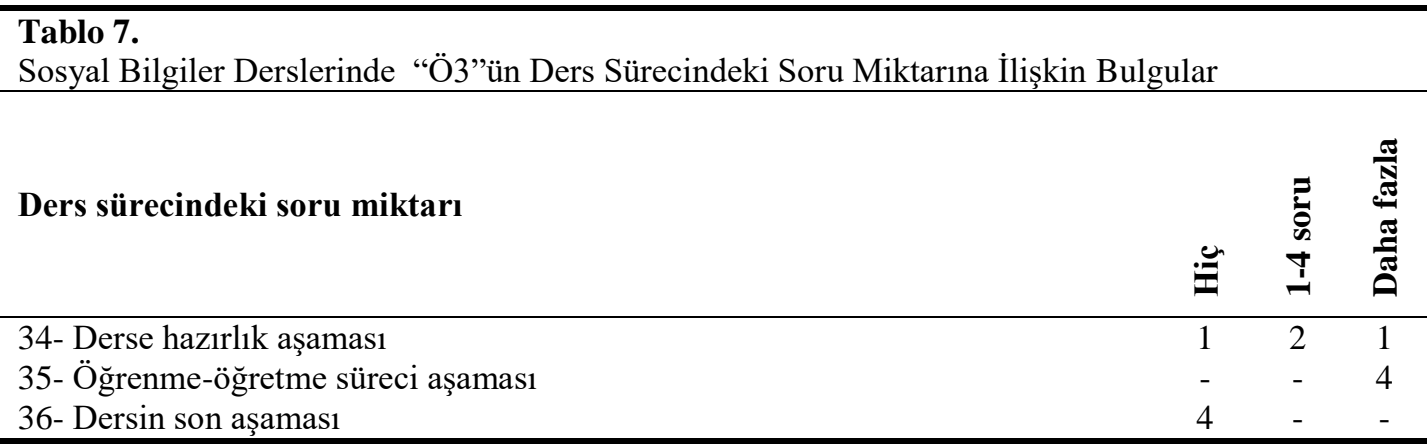

Sınıf içi yapılan gözlemlerde Ö3 dersin başlangıç kısmında sorular sormuştur ancak en fazla soruyu öğrenmeöğretme süreci esnasında yöneltmiştir. Dersin sonuç bölümü genelde gözlemlenmemiş ya öğrenme-öğretme süreci esnasında zil çalmış ya da kayıt bitmiştir. Konunun bitiminde soru sorma davranışı pek gözlemlenmemiştir.

Ö3 soru sorma süreçleri hakkında gözlemler bittikten sonra yapılan görüşmede derslerde sorulara ne kadar yer verdiğine ilişkin şunları söylemiştir:

"Giriş kısmında daha çok ă̆ırllk veriyorum. Bir önceki konuyla bağlantı yapmam gerekiyor çünkü. Sorularla ön bilgiler yoklanıyor geçmiş bilgiler de yoklanmış oluyor. Ondan sonra ben onun üzerine ders anlattyorum. Dersin yaklaşık son zamanları daha çok soru soruyorum toparlama adına. O derste o bilgiler alınmış mı ya da eksikler nerelerde bunu tespit edebilme adına çeşitli notlar allyorum kitaplarıma şu kısmında yine problem var. Bir dahaki dersin girişinde bu kisma değinerek başla gibi. Notlarım oluyor."

Ö3 dersin girişinde ve son bölümlerinde daha çok soru sorduğunu ifade etmiştir. Gözlem sonuçlarına bakıldığında ise Ö3'ün derse genellikle soru sorarak başladığı ancak soruları en çok öğrenme-öğretme süreçleri esnasında sorduğu gözlemlenmiştir. Bu durum Ö3'ün görüşmedeki ifadelerini desteklemektedir. Öğretmenin dersin bitiminde soru sorduğuna ilişkin ifadesi ise gözlem bulgularıyla çelişmektedir.

\begin{tabular}{|c|c|c|c|}
\hline Soruların düzeyi & $\ddot{ت}$ & 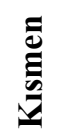 & $\ddot{\theta}$ \\
\hline 29- Basit hatırlama ve bellek soruları sorar. & 1 & - & 5 \\
\hline 30- Yakınsak sorular: Kabul edilebilir tek cevabı olan sorular sorar. & 1 & - & 5 \\
\hline 31- Iraksak sorular: Birkaç muhtemel cevabı olabilecek sorular sorar. & 3 & 3 & - \\
\hline 32- Değerlendirme soruları: Yargı bildiren sorular sorar. & 4 & 2 & - \\
\hline $\begin{array}{l}\text { 33- İşleyişle ilgili sorular: Organizasyon, disiplin ve dersin yapısıyla ilgili sorular } \\
\text { sorar. }\end{array}$ & 6 & - & - \\
\hline
\end{tabular}

Öğretmen gözlemlenen derslerde öğrencilere sıklıkla basit hatırlama ve bellek soruları ile kabul edilebilir tek cevabı olan yakınsak sorular sormuştur. Ayrıca öğretmen kısmen ıraksak yani birkaç muhtemel cevabı olabilecek sorular da sormuştur. Ö4 değerlendirme düzeyinde az soru sormuş olup işleyişle hiç soru sormamıştır.

Elde edilen bu bulgulara kanıt olabilecek soru düzeylerini yansıtan soru-cevap diyalog örnekleri aşağıda verilmiştir.

Ö4: Kösedăg Savaşı Sonrası Moğollar Anadolu'yu istila edecek ve Anadolu Selçuklu Devleti ylkılacak. Anadolu'da yeniden hani Anadolu'da ilk Türk beyliklerinden bahsetmiştik ya hatırlyorsunuz değil mi ilk Türk beyliklerini? Neydi onlar? 
Öğrenci: Çaka Beyliği

Ö̆renci: Artuklular

Ö4: Evet, beş taneydiler. Tekrar edelim onlart. Danişmentliler, Saltuklular, Artuklular, Mengücekliler, Çaka Beyliği bir de Anadolu Selçuklu Devleti.

Bu diyalogda öğretmen Kösedağ Savaşı sonrasında kurulan ilk Türk beyliklerinin hangileri olduğunu sormaktadır. $\mathrm{Bu}$ hatırlamaya yönelik bir soru olduğu için basit hatırlama ve bellek sorusu olarak değerlendirilebilir.

Ö4: Soruya bakallm şimdi kervansaraylar genellikle yüksek duvarlarla örülmüss etrafi neden? Neden böyle bir şey yapılmış? Parmak istiyorum evet (Öğrencinin adını söyler)

Öğrenci: Ateş etmesinler diye.

Ö4: Korunmak amacıyla diyorsun. Güvenlik amacıyla aferin doğru peki bașka ne olabilir?

Başka Öğrenci: Hırsızlık yapılmasın diye.

Ö4: Hırsızllk yapılmasın diye olabilir hayvanları çalmasınlar eşyaları çalmasılnlar diye aferin evet bu da var. Bakın en önemli sebep güvenlik.

$\mathrm{Bu}$ diyalogda öğretmen öğrencilerine kervansarayların yüksek duvarlarla örülme sebebini sormaktadır. Bu sorunun cevabı hemen herkesçe aynı verileceği için yakınsak soru türü olarak değerlendirilmiştir.

Ö4: Yani ülke bütün Hükümdarın çocuklarl yani Hükümdar ailesi arasinda paylaştırlllyor. Hükümdar ne yapıyor? Bütün aile bireylerine çocuklarına ne yapıyor? Ülkeyi paylaştırıyor? Peki, bunun ne zararı var? Kim söyleyecek? Öğrenci: Hocam, ülkeyi paylaştırdiklarında kavga ederler ve ayrllırlar birbirleriyle kavga ederler.

Ö4: Birbirleriyle kavga ederler evet.

Başka Öğrenci: Yerler azalır hocam.

Ö4: Nasil?

Öğrenci: Ülkenin yeri azalır.

Ö4: Yeri azalır tamam başka ne olabilir? Mesela düşünün hani bizim bir sözümüz var ya hani "bir elin nesi var iki elin sesi var" ya da başka bir ifadeyle birlikten kuvvet doğar. Şimdi mesela birlikten kuvvet doğarsa bölünüp parçalandığımız zaman kuvvet olur mu?

Öğrenci: Hayır.

Ö4: Yani birleştiğimiz zaman daha kuvvetli oluruz doğru mu Mehmet Ali? Ama bölünüp parçalandlğımız zaman kuvvetimiz...

Ögrenci: Azalir.

$\mathrm{Bu}$ diyalogda öğretmen öğrencilerine bir ülkenin hükümdar çocukları arasında paylaştırılmasının ne gibi sakıncaları olabileceğini sormaktadır. Farklı cevaplar verilebileceği gibi biraz daha yorum gerektiren bir soru olduğu için ıraksak (birden fazla cevabı olan)soru türü olarak değerlendirilmiş̧ir.

\begin{tabular}{l}
\hline Tablo 9. \\
Sosyal Bilgiler Derslerinde “Ö4” ün Ders Sürecindeki Soru Miktarına İlişkin Bulgular \\
\\
Ders sürecindeki soru miktarı
\end{tabular}

Gözlem sonuçlarına göre Ö4 dersin başlangıcında sorular sormuş ancak en çok soruyu öğrenme-öğretme süreçleri esnasında sormuştur. İzlenen derslerde sonuç bölümü gözlemlenmemiş genelde öğrenme-öğretme süreci esnasında zil çalmış ya da kayıt sona ermiş̧ir.

Ö4 öğretmeni soru sorma süreçleri hakkında gözlemler bittikten sonra yapılan görüşmede derslerde sorulara ne kadar yer verdiğine ilişkin şunları söylemiştir:

"Evet, șimdi mümkün olduğunca sorulara konuların arasında, konuların bitiminde zaten projeksiyonla ders işlediğim zaman aralara o soruları serpiştirdik. Powerpoint'te hazırladı̆̆ı̆ız soruları serpiştiriyoruz. Konu 
işlenirken aralarda. Hazırlıkta şöyle yapıyoruz. Kitaptaki soruları, hazırlı sorularını... Mesela bugün hazırlık sorularını o şekilde yaptık. Konunun öncesinde kitaptaki hazırlık sorusunu konuşuyoruz derse geçtikten sonra konu aralarında işlediğimiz ders, işlenen konunun durumuna göre aralarda soru soruyoruz. Bazen de konunun bitiminde konunun ne kadar anlaşıldı̆̆ına dair değerlendirme soruları yapıyoruz."

Ö4 kendisiyle yapılan görüşmede derslerinde soruları en fazla konuların arasında ve bitiminde sorduğunu ifade etmiştir. Gözlem sonuçlarına bakıldığında ise Ö4'ün derse genellikle soru sorarak başladığı ancak soruları en çok öğrenme-öğretme süreçleri esnasında sorduğu gözlemlenmiştir. Bu durum Ö4'ün görüşmedeki ifadelerini desteklemektedir. Öğretmenin dersin bitiminde soru sorduğuna ilişkin ifadesi ise gözlem bulgularıyla çelişmektedir.

\section{Tartışma ve Sonuç}

İzlenen derslerde sosyal bilgiler öğretmenlerinin en çok alt düzeyde nitelendirilebilecek basit hatırlama ve bellek sorusu ile yakınsak sorular yani kabul edilebilir tek cevabı olan türde sorular sorduğu sonucuna ulaşılmıştır. Öğretmenler öğrencilere değerlendirme yani yargı bildiren sorular da yöneltmiştir ancak raksak sorular yani birkaç muhtemel cevabı olabilecek düzeyde soruların az sorulduğu, işleyişle ilgili soruların ise hiç sorulmadığı tespit edilmiştir. Öğrencilere işleyişle ilgili sorular yöneltilmesinin dersin planlanabilmesi, öğrencilerin de öğrenme sürecinin içine dâhil edilebilmesi ve öğrenme sürecinin değerlendirmesi adına önemli olduğu söylenebilir. Derslerde bu türden soruların hiç sorulmamış olması öğretmenlerin yapılandırmacı ve öğrenci merkezli eğitim anlayışını benimseseler de otoriter olmaktan kurtulamadığı ve öğrencilerin görüşlerine çok da önem vermedikleri şeklinde yorumlanabilir.

Araştırmaya katılan öğretmenlerden Ö2 ve Ö3'ün izlenen derslerin hemen hepsinde yakınsak (kabul edilebilir tek cevabı olan) düzeyde soruların yanı sıra ıraksak (birkaç muhtemel cevabı olabilecek) soruları ve değerlendirme sorularını yoğun olarak sordukları tespit edilmiştir. Ö2'nin eğitim fakültesinden önce sosyoloji bölümünde de öğrenim görmüş olması ve felsefe grubu derslerine hâkim oluşunun bunda etkili olduğu düşünülmektedir. Ö3 de özel okulda çalsştı̆̆ için sosyal bilgiler ders saati devlet okulundakinden bir ders saati fazladır. Zaman problemi yaşamamakta ve seviyesi yüksek sayılabilecek öğrencilerle çalışmaktadır. Bu yüzden de onları zihinsel anlamda zorlayacak türde soruları sormayı tercih ettiği söylenebilir.

Ö1 ve Ö4 izlenen derslerde daha çok hatırlama boyutunda ve yakınsak düzeyde sorular sormuşlardır. Ö1 ile yapılan görüş̧ede "Ben çocukların beynini yorabileceği, sentez yapabileceği ve yorum yapabileceği soruları çok seviyorum." demiş olmasına rağmen alt düzeyde sorular sorduğu tespit edilmiştir. Öğretmenin 5. ve 6.sınıflarda gözlemlenmiş olması bunun sebebi olabilir çünkü bu sınıflarda öğrenciler biraz daha somut düşünmekte ve sorulan sorulara üst düzey cevaplar alabilme daha sınırlı olmaktadır. Yine de bu durum öğretmenin teorik anlamda benimsediklerini uygulamaya yansıtmakta sıkıntı yaşadığını gösterdiği şeklinde yorumlanabilir. Ö4 de liselere giriş sınavlarında ilçe sıralamasında sonuncu sırada bulunan bir okulda çalışmaktadır. Sınıflarında öğrenci seviyesi çok düşüktür. Buna rağmen yakınsak ve değerlendirme düzeyinde sorular sorduğu da gözlemlenmiştir. Koray ve Yaman (2002), Dindar ve Demir (2006), Aydemir ve Çiftçi (2008), Çolak ve Demircioğlu (2010), Kılıç (2010), Kavruk ve Çeȩen (2013) öğretmenlerin hazırladığı sınav sorularını, Baysen (2006), Can (2006), Bektaş ve Şahin (2007), Beskisiz (2009), Khan ve Inamullah (2011) öğretmenlerin ders sürecinde kullandığı soruları incelemiştir. $\mathrm{Bu}$ araştırmalarda sınav sorularının ve öğretmenlerin ders süreçlerinde kullandığı soruların genelde bilgi ve kavrama basamağında toplandığı sonucuna varılmış̧ır. Bu araştırma sonucunda elde edilen öğretmenlerin daha çok hatırlama ve yakınsak düzeyde sorular sorduğu bulgusu adı geçen araştırma sonuçlarıyla örtüşmektedir. Lakin Çalışkan (2011) yapmış olduğu araştırmada sosyal bilgiler öğretmenlerinin sınavlarda hala alt düzey soruları yoğunlukla kullanmalarına rağmen yapılandırmacı eğitim anlayışına geçilmesinin bir sonucu olarak bilgi düzeylerinde azalma, kavrama, uygulama, analiz ve sentez, değerlendirme düzeyindeki sorularda artış olduğu sonucuna ulaşmıştır. Sınavlardaki bu durum sınıf içi ders süreçlerinde de benzer şekildedir. Davranış̧̧ı programa göre üst düzey soruların varlığında artış gözlemlenmektedir ancak bu tür soruların sorulma oranı hala yetersizdir. $\mathrm{Bu}$ araştırmada da izlenen tüm derslerde birçok soru sorulmuştur. Yapılandırmacı eğitim anlayışında dersin hazırlık bölümü çok önemlidir bu aşamada öğretmenler ön bilgileri yoklayıcı sorular sorarak öncelikle öğrencilerin o gün işlenecek konu hakkındaki ön bilgilerini, konuya ne kadar hazır olduklarını tespit eder. Ayrıca kazanımları işaret eden bir takım sorularla öğrencinin zihnini uyarır ve harekete geçirir. Öğrencilerin motive olmasında bu aşama çok önemlidir.

Araştırmada öğretmenler genel olarak derse hazırlık aşamasında giriş itibariyle kısmen/yeterli denilebilecek düzeyde sorular sormuşlardır. Dersin giriş kısmında Ö1, Ö2 ve Ö3 yeterli miktarda soru sormuştur ancak Ö4'ün izlenen derslerde hazırlık bölümünde soru sorma davranışı çok az gözlemlenmiştir. İzlenen derslerden anlaşıldığı 
kadarıyla öğretmenlerin dersin bu bölümünün öneminin farkında olmadıkları ya da bu bölümü ihmal ettikleri söylenebilir. Bunun nedeni yapılandırmacı eğitim anlayışının tam olarak bilinmemesi ve derslere uygulanamaması olabilir.

İzlenen bütün derslerde dört öğretmen de en fazla soruyu öğrenme-öğretme süreci esnasında sormuşlardır. Hangi yöntem kullanılırsa kullanılsın derslerin bu bölümünde çok fazla soru sorulmuştur. Tüm öğretmenler yapılan görüşmelerde soru sormanın çok önemli olduğunu ve ders sürecinin sorular olmadan eksik kalacağını ifade etmişlerdir. Öğretmenlerin bu ifadesi araştırmadan elde edilen sonuçlarla örtüşmektedir.

Derslerin sonuç bölümlerinde ise soru sorma davranışının çok az olduğu tespit edilmiştir. Çünkü izlenen derslerde dersin sonuç bölümü gözlemlenememiştir. Dersin sonuç bölümünde sorulan sorular da önemlidir. Çünkü öğretmene öğrenmenin ne kadar gerçekleştiği ya da gerçekleşemediği noktasında bilgi sağlar. Konunun anlaşılıp anlaşılmadığı verisini sunar. Dersin sonunda sorulan sorular sayesinde öğretmen kazanımlara ne kadar ulaşıldığına dair bir değerlendirme yapabilir ve bir sonraki dersini buna göre planlar. Öğretmenler dersin sonunda genelde “öğrencilere sormak istediğiniz bir şey var mı?” anlayışılla yaklaşsa da genelde öğrenme-öğretme süreci esnasında zil çalmış ya da kayıt sona ermiştir. Buradan öğretmenlerin derste süreç yönetimini verimli hale getiremediği, planlamada sıkıntılar yaşadıkları söylenebilir.

Gözlem ve görüşmelerden elde edilen verilerin değerlendirilmesi ile sosyal bilgiler öğretmenlerinin en çok alt düzeyde nitelendirilebilecek basit hatırlama ve bellek sorusu ile yakınsak sorular yani kabul edilebilir tek cevab1 olan türde sorular sorduğu sonucuna ulaşılmıştır. Öğretmenler öğrencilere değerlendirme soruları da yöneltmiştir ancak ıraksak soruların az, işleyişle ilgili soruların ise hiç sorulmadığı tespit edilmiştir. Öğretmenler en fazla soruyu öğrenme-öğretme süreçleri esnasında sormuş derslerin giriş bölümünde az soru sorulmuş sonuç bölümlerinde ise soru sorma davranışı gözlemlenmemiştir.

\section{Öneriler}

Araştırmanın sonuçlarından yola çıkılarak sosyal bilgiler öğretmenlerine;

- Alt düzeyde nitelendirilebilecek basit hatırlama ve bellek sorusu ile yakınsak sorular yani kabul edilebilir tek cevabı olan türde soruların haricinde üst düzey düşünmeyi teşvik edecek raksak düzeyde ve değerlendirmeye yönelik sorular sormaya özen göstermeleri,

- Yaratıcı düşünce ve problem çözme becerilerini geliştirici türde soruları daha fazla sormaları,

- Dersin tüm bölümlerinde konuya, kazanıma göre ön bilgileri harekete geçirici ve dersin sonunda da öğrenmeleri tespit edebilecekleri ölçüde sorular sormaya dikkat etmeleri önerilmektedir.

Araştırmacılara;

- Sosyal bilgiler öğretmenlerinin nasıl sorular sorduklarına yönelik araştırmaların arttırılması,

- Öğrencilerin sosyal bilgiler dersinde nasıl sorular sorduklarına yönelik araştırmaların yapılması,

- Sorulan soruların özelliklerinin yanı sıra soru sorma stratejilerinin araştırılması,

- Öğretmenlere soru sormaya yönelik farklı öğretim programları sunularak sonuçlarının araştırılması önerilmektedir. 


\section{References}

Açıkgöz, K. Ü. (2003). Etkili Öğrenme ve Öğretme. İzmir: Eğitim Dünyası.

Açıkgöz, K. Ü. (2014). Aktif öğrenme. [Active learning] İzmir: Biliş Publishing

Akbulut, T. (1999). Illköğretim okullarında görevli öğretmenlerin soru sorma becerilerinin bazı değisskenler açısından incelenmesi. [The Evaluation of questioning skills of primary school teachers in terms of certain variables]. Çukurova University Institution of Social Sciences, Master's thesis, Adana, Turkey.

Aydemir, Y. \& Çiftçi, Ö. (2008). Edebiyat öğretmeni adaylarının soru sorma becerileri üzerine bir araştırma (Gazi Üniversitesi Eğitim Fakültesi örneği). [A research on asking question ability of literature teacher candidates Gazi Univesity Education Faculty pattern] Journal of Yüzüncü Yll University Faculty of Education, 5(2), 103-115.

Baysen, E. (2006). Öğretmenlerin sınıfta sordukları sorular ile öğrencilerin bu sorulara verdikleri cevapların düzeyleri. [The levels of teacher questions and student answers] Kastamonu Education Journal, 14(1), 21-28.

Bektaş, E. \& Şahin, A.E. (2007). İlköğretim beşinci sınıf öğretmenlerinin soru-yanıt tekniğini kullanım davranışlarının analizi. [A analysis of fifth grade elementary school teachers' questioning behaviors]. Eurasian Journal of Educational Research, 28, 19-29.

Beskisiz, E. (2009) Beşinci sinıf ögretmenlerinin öğrenme stillerine göre sosyal bilgiler dersinde sordukları soru türleri ve bilişsel düzeylerinin incelenmesi. [Consideration of sort of questions which 5th grade teachers ask according to the learning styles and their cognitive levels in social studies lesson]. (Master thesis). Çukurova University, Adana

Büyükalan Filiz, S. (2004). Öğretmenler için soru sorma sanatı. [The art of asking questions for teachers] Ankara: Asil Publishing

Can, R. (2006). Türk dili ve edebiyatı ögretmenlerinin soru sorma becerileri üzerine bir alan araştırmast. [A branch study about the asking question ability of Turkish language and literature teachers (secondary education first grade-in classroom activities)]. (Master thesis). GaziUniversity, Ankara

Çalışkan, H. (2011). Öğretmenlerin hazırladığı sosyal bilgiler dersi sorularının değerlendirilmesi. [An evaluation of the teacher-made social studies course exam questions] Education and Science, 36 (160), 120-132.

Çolak, K. \& Demircioğlu, İ.H. (2010). Tarih dersi sınav sorularının Bloom Taksonomisi'nin bilişsel alan düzeyi açısından sınıflandırılması. [Classification of history exam questions according to cognitive levels of Bloom's taxonomy] Millî Ĕgitim, 187, 160-171.

Demirkaya, H. (2011). Sosyal bilgilerde düşünme ve soru sorma becerileri. [Thinking and asking questions in social studies ]B. Tay \& A. Öcal (Editör). Özel ögrretim yöntemleriyle sosyal bilgiler öğretimi içinde (in social studies teaching with special methods)(p. 400-434). Ankara: Pegem Akademi

Dindar, H. \& Demir, M. (2006). Beşinci sınıf öğretmenlerinin fen bilgisi dersi sınav sorularının Bloom Taksonomisine göre değerlendirilmesi. [Evaluation Of Fifth Grade Primary Teachers' Questions In Science Exams According To Blooms Taxanomy] Gazi Journal of Educational Science, 26(3), 87-96.

Glesne, C. (2013). Nitel araştırmaya giriş. (A. Ersoy \& P. Yalçınoğlu, trans.). [Becoming Qualitative Researchers: An Introduction] Ankara: Anı Publishing

Kavruk, H. \& Çeçen, M.A. (2013). Türkçe dersi yazılı sınav sorularının bilişsel alan basamakları açısından değerlendirilmesi. [Evaluation of Turkish Language Class Exam Questions in Point of Cognitive Field Levels]. Journal of Mother Tongue Education, 1(4), 1-9.

Kılı̨̧, D. (2010). Sosyal bilgiler ögretmenlerinin tarih konuları ile ilgili soru sorma becerilerinin Bloom Taksonomisine göre değerlendirilmesi. [Evaluation of social sciences teachers' questioning skills about subject of history according to Bloom Taxonomy]. (Master thesis). Marmara University, İstanbul

Khan, W.B. \& Inamullah, H.M. (2011). A study of lower-order and higher-order questions at secondary level. Asian Social Science, 7(9), 149-157.

Koray, C.Ö. \& Yaman, S. (2002). Fen bilgisi öğretmenlerinin soru sorma becerilerinin Bloom Taksonomisine göre değerlendirilmesi. [An Assessment of Questioning Skills of Science Teacher According to Bloom's Taxonomy] Gazi University Kastamonu Education Journal, 10(2), 317-324.

Köse, E. (2010). Bilimsel araştırma modelleri. [Scientific research models] R.Y. Kıncal (Editör). Bilimsel araştırma yöntemleri içinde (s. 97-120). [in scientific research methods ]Ankara: Nobel pub.

Özden, Y. (2003). Öğrenme ve ögretme. [Learning and teaching ]Ankara: PegemA Publishing

TDK. (2000). Türkçe sözlük. [Turkish Dictionary] Ankara: Türk Dil Kurumu Publishing 
Selçuk, Z. (2001). Okul deneyimi ve uygulama. [School experience and practice ]Ankara: Nobel pub.

Sönmez, V. (2001). Program geliştirmede ögretmen elkitabı. [Teacher manual in program development] Ankara: Anı Publishing

Şevik, M. (2005). Yabancı dil öğretiminde sorular, öğrenci cevapları ve öğretmen davranışları. [Questions, student responses, and teacher behaviours in the teaching of modern foreign languages] Ankara University, Journal of Faculty of Educational Sciences, 38(2), 1-19.

Yıldırım, A. \& Şimşek, H. (2011). Sosyal bilimlerde nitel araştırma yöntemleri [Qualitative research methods in the social sciences](8.Baskı). Ankara: Seçkin Yay. 